\title{
Evolução da região de Santana do Araguaia (PA) com base na geologia e geocronologia $\mathrm{Pb}-\mathrm{Pb}$ em zircão de granitoides

\author{
Evolution of the Santana do Araguaia (PA) region based on geology and Pb-Pb zircon \\ geochronology from granitoid rocks
}

\author{
Lívio Wagner Chaves Corrêa ${ }^{1}$ e Moacir José Buenano Macambira ${ }^{1}$ \\ ${ }^{1}$ Laboratório de Geologia Isotópica, Instituto de Geociências, Universidade Federal do Pará - UFPA, Caixa Postal 8608, \\ CEP 66075-110, Belém, PA, BR (livio_correa@yahoo.com.br; moamac@ufpa.br)
}

Recebido em 24 de abril de 2013; aceito em 14 de março de 2014

\begin{abstract}
Resumo
A região de Santana do Araguaia, foco deste trabalho, localiza-se no sudeste do Estado do Pará, que, por sua vez, fica no sudeste do Cráton Amazônico. Sob o ponto de vista tectônico, posiciona-se no Domínio Santana do Araguaia, interpretado como um terreno arqueano afetado pelo Ciclo Transamazônico. Um estudo petrográfico e geocronológico, com suporte de dados de campo, foi empreendido em granitoides da região com o intuito de desvendar a evolução desse domínio. Em termos modais, as rochas estudadas compõem-se de biotita monzogranito, biotita metagranodiorito, hornblenda-biotita granodiorito, hornblenda-biotita metatonalito e enderbito. Essas rochas apresentam-se não deformadas a moderadamente deformadas, com algumas particularidades: o biotita metagranodiorito apresenta foliação seguindo um trend E-W; o hornblenda-biotita metatonalito possui uma foliação seguindo a direção NW-SE, com mergulhos normalmente altos a subverticais; o biotita monzogranito é isotrópico e os litotipos hornblenda-biotita granodiorito e enderbito apresentam apenas uma leve orientação de seus cristais, perceptível principalmente em lâmina delgada. Esses litotipos foram analisados pelo método de evaporação de $\mathrm{Pb}$ de zircão, tendo sido obtidas as seguintes idades: biotita metagranodiorito, $3066 \pm 3 \mathrm{Ma}$ e $2829 \pm 13$ Ma, hornblenda-biotita metatonalito, $2852 \pm 2$ Ma; biotita monzogranito (ML-08), 2678 a 2342 Ma; hornblendabiotita granodiorito, $1990 \pm 7 \mathrm{Ma}$; e enderbito, $1988 \pm 4 \mathrm{Ma}$. Os dados geocronológicos indicam que as rochas cristalizaram tanto no Arqueano quanto no Paleoproterozoico, contudo, não foram detectadas evidências que comprovem a ação do Ciclo Transamazônico na região.
\end{abstract}

Palavras-chave: Santana do Araguaia; Granitoides; Geocronologia; Arqueano; Paleoproterozoico.

\begin{abstract}
The region of Santana do Araguaia, focus of this study, is located in the southeast of Pará State, which, in its turn, lies in the southeastern Amazonian Craton. From the tectonic point of view, it is positioned in the Domain Santana do Araguaia, interpreted as an Archean terrain affected by the Transamazonic Cycle. A petrographic and geochronological study, supported by field data, was undertaken in granitoids of the region in order to unravel the evolution of this field. In modal terms, the studied rocks consist of biotite monzogranite, biotite metagranodiorite, hornblende-biotite granodiorite, hornblende-biotite metatonalite and enderbite. These rocks present themselves undeformed to moderately deformed, with some particularities: the biotite metagranodiorite presents foliation following an E-W trend; the hornblende-biotite metatonalite has a foliation following the NW-SE direction, usually with high to subvertical dives, the biotite monzogranite is isotropic, and lithologies hornblende-biotite granodiorite and enderbite show only a slight orientation of their crystals, mainly noticeable in thin section. These rock types were analyzed by evaporating $\mathrm{Pb}$ zircon method and the following ages were obtained: biotite metagranodiorite, $3066 \pm 3 \mathrm{Ma}$ and $2829 \pm 13 \mathrm{Ma}$, hornblende-biotite metatonalite, $2852 \pm 2 \mathrm{Ma}$, biotite monzogranite, 2678 to $2342 \mathrm{Ma}$, hornblende-biotite granodiorite, $1990 \pm 7 \mathrm{Ma}$, and enderbite, $1988 \pm 4 \mathrm{Ma}$. The geochronological data indicate that the rocks crystallized both in the Archean and in the Paleoproterozoic; however, no evidence to prove the action of the Transamazonic Cycle was detected in the region.
\end{abstract}

Keywords: Santana do Araguaia; Granitoids; Geochronology; Archean; Paleoproterozoic. 


\section{INTRODUÇÃO}

Nas propostas de compartimentação tectônica do Cráton Amazônico, o Domínio Santana do Araguaia tem sido considerado uma continuidade do Terreno Granito-Greenstone de Rio Maria (TGGRM), de idade mesoarqueana (3000 $2860 \mathrm{Ma}$ ), sendo, portanto, interpretado como pertencente à Província Carajás (Santos, 2003) ou à Província Amazônia Central (Tassinari e Macambira, 1999, 2004). No entanto, os estudos realizados por Macambira et al. (2007) e Vasquez et al. (2008) levaram a visualizar, com base em novos dados geocronológicos obtidos pelo método de evaporação de $\mathrm{Pb}$ em zircão, um quadro geológico diferente. Segundo os autores, naquela região teria havido um retrabalhamento de rochas arqueanas durante o Ciclo Transamazônico, levando-os a individualizar, com base nesse fato, o Domínio Santana do Araguaia (DSA). Apesar dos trabalhos recentes (Macambira et al., 2007; Vasquez et al., 2007, 2008), a região de Santana do Araguaia ainda é um dos setores pouco conhecidos do território paraense, sendo poucos os dados geocronológicos para essa região. Em função disso, há incertezas quanto ao posicionamento cronoestratigráfico dos granitoides e o real significado do DSA. O método de datação por evaporação direta de $\mathrm{Pb}$ em zircão é uma ferramenta que pode ser adequada, apesar de algumas limitações, para a determinação da idade de cristalização de rochas antigas. No presente trabalho, esse método foi aplicado em amostras de granitoides coletadas na região de Santana do Araguaia, com o objetivo de definir as idades das mesmas, contribuindo para uma melhor definição do quadro litoestratigráfico local. Isso permite confrontá-lo com os dados geocronológicos dos granitoides do TGGRM para melhor entender a relação entre os dois domínios.

\section{CONTEXTO GEOLÓGICO REGIONAL}

O Cráton Amazônico tem sido subdividido em várias províncias geocronológicas que apresentam idades diferentes, distintos padrões estruturais e evoluções geodinâmicas particulares (Figura 1). A Província Carajás (Santos, 2003), ou Província Amazônia Central (Tassinari e Macambira, 1999, 2004), tem sido considerada como a parte mais antiga do cráton, em cuja extremidade meridional se encontra a área de estudo.

\section{Domínio Rio Maria}

O Domínio Rio Maria (DRM) é o domínio que apresenta as rochas mais antigas da Província Carajás. É formado por Greenstone belts (Supergrupo Andorinhas) e por cinco grupos principais de granitoides arqueanos (Pimentel e
Machado, 1994; Macambira e Lafon, 1995; Althoff et al., 2000, Leite, 2001; Leite et al., 2004; Dall'Agnol et al., 2006; Oliveira et al., 2009; Almeida et al., 2010, 2011), a saber:

- Séries TTGs mais antigas formadas em dois episódios distintos, sendo o mais antigo $(2960 \pm 0,02 \mathrm{Ma})$ representado pelo Tonalito Arco Verde e Trondhjemito Mogno (2965 Ma), seguido em $2930 \pm$ 0,02 Ma pela formação do Complexo Tonalítico Caracol, Tonalito Mariazinha e Tonalito Arco Verde;

- Granitoides dominantemente granodioríticos com alto Mg (2870 Ma), formados pelo Granodiorito Rio Maria e por rochas intermediárias e máficas associadas de afinidade sanuquitoide;

- Leucogranodioritos e leucomonzogranitos cálcio-alcalinos enriquecidos em $\mathrm{Ba}$ e $\mathrm{Sr}$, representados pela Suíte Guarantã e granitos similares (2870 Ma);

- TTGs mais jovens, correspondentes ao Trondhjemito Água Fria (2860 Ma);

- Leucogranitos potássicos (2860 Ma), representados pelos granitos Xinguara, Mata Surrão e similares.

Durante o Paleoproterozoico, mais precisamente em torno de $1880 \mathrm{Ma}$, o DRM foi palco de um amplo magmatismo granítico anorogênico, que afetou as suas diferentes unidades litoestratigráficas. Os granitos tipo A oxidados, intrusivos em rochas arqueanas do DRM, foram agrupados na Suíte Jamon, e os granitos tipo A moderadamente reduzidos, intrusivos em rochas arqueanas da bacia Carajás, foram englobados na Suíte Serra dos Carajás (Dall'Agnol et al., 1999, 2005, 2006). Os dados geocronológicos para o DRM e o DSA estão sumarizados na Tabela 1.

\section{Domínio Santana do Araguaia (DSA)}

O Domínio Santana do Araguaia localiza-se no sudeste do Cráton Amazônico, com limites a leste e a norte com o TGGRM, a oeste com o Domínio Iriri-Xingu e a sul com a Bacia do Parecis e Cinturão Araguaia (Figura 2).

Estudos anteriores consideravam este setor como uma continuidade do TGGRM, porém dados geocronológicos (Tabela 1), Macambira et al. (2007) e Vasquez et al. $(2007,2008)$ sugerem que o DSA teria sofrido um retrabalhamento durante o Evento Transamazônico e individualizam tal setor, correlacionando-o à Província Transamazonas (Santos, 2003) ou à província MaroniItacaiúnas (Tassinari e Macambira, 2004). Nesses trabalhos, um novo arranjo litoestratigráfico foi proposto, que estaria representado pelas seguintes unidades: Sequência Mururé, Sequência Fazenda Santa Fé, Ortognaisse Rio Campo Alegre, Complexo Santana do Araguaia, Tonalito Rio Dezoito, Rochas Supracrustais e Granitos Paleoproterozoicos. Foi igualmente caracterizada uma forte estruturação de direção NW-SE. 


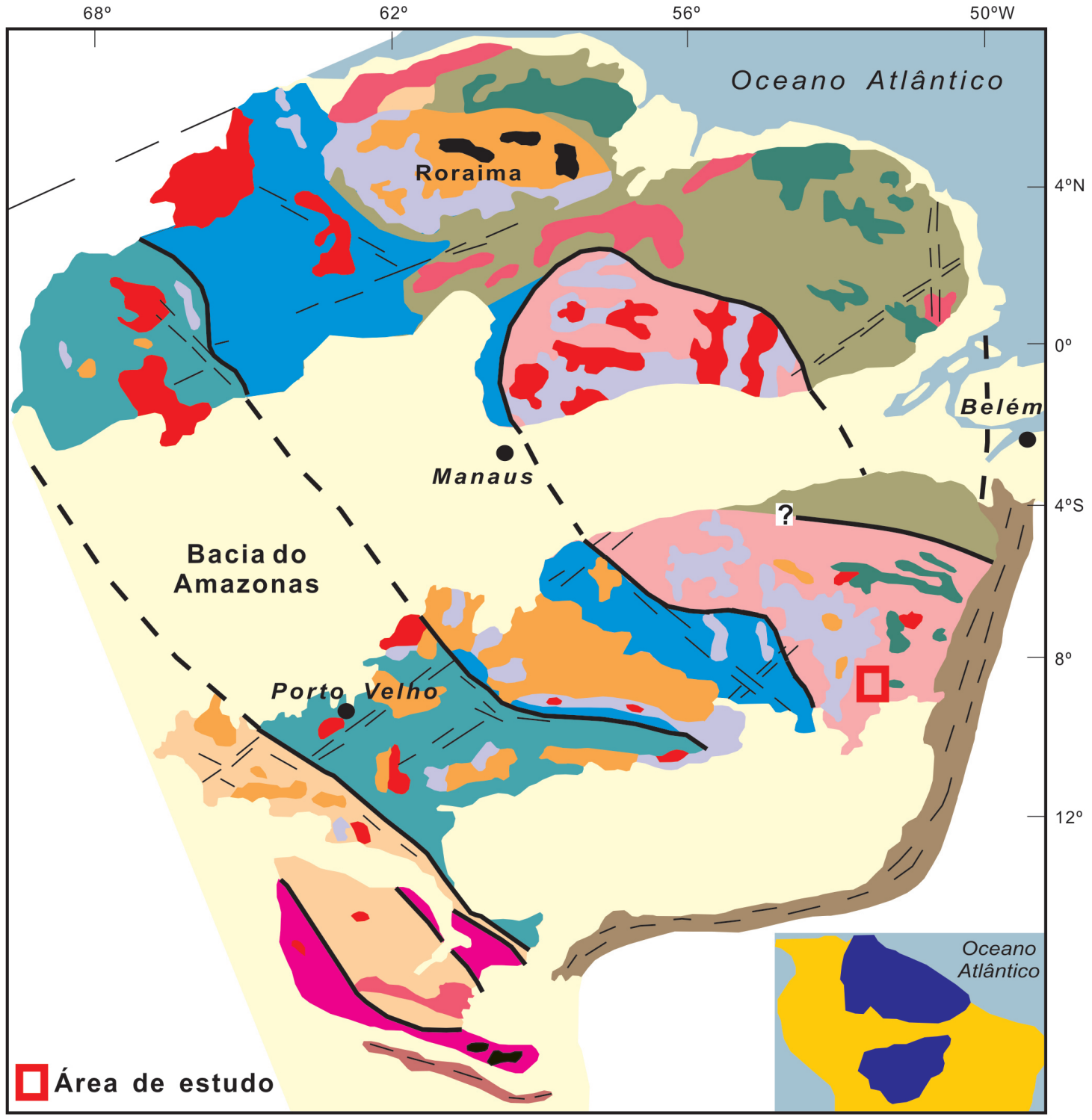

Províncias geocronológicas

Amazônia Central $>2,5 \mathrm{Ga}$

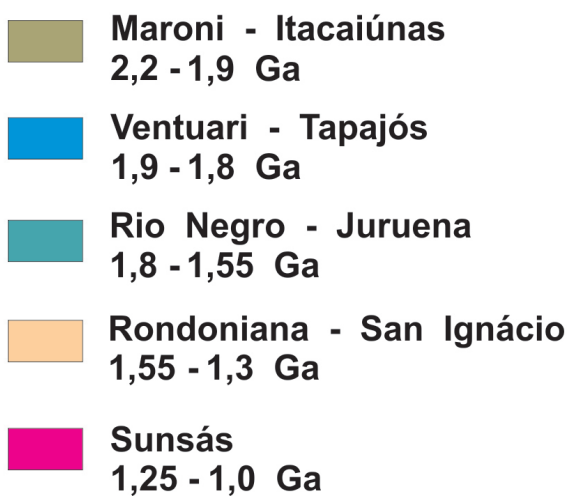

Unidades geológicas

Cobertura fanerozoica

Granitoide

Cobertura sedimentar pré-cambriana

Vulcanismo ácido intermediário

Vulcanismo máfico

Greenstone belt

Complexo granulítico

Faixas neoproterozoicas

_ - Alto estrutural do embasamento

Figura 1. Províncias geocronológicas do Cráton Amazônico (modificado de Tassinari e Macambira, 2004). 
Tabela 1. Principais dados geocronológicos para rochas do Domínio Rio Maria e do Domínio Santana do Araguaia (PA).

\begin{tabular}{|c|c|c|c|c|}
\hline Unidades estratigráficas & Tipo de rocha & Método & $\begin{array}{c}\text { Material } \\
\text { analisado }\end{array}$ & Idade (Ma)/referência \\
\hline \multicolumn{5}{|c|}{ Domínio Santana do Araguaia } \\
\hline Suíte Intrusiva Rio Dourado & Granito & $\mathrm{U}-\mathrm{Pb}$ & Zircão & $1889 \pm 11(1)$ \\
\hline Tonalito Rio Dezoito & Tonalito & $\mathrm{Pb}-\mathrm{Pb}$ & Zircão & $2187 \pm 28(2)$ \\
\hline \multirow[t]{4}{*}{ Complexo Santana do Araguaia } & Granitoide & $\mathrm{K}-\mathrm{Ar}$ & Muscovita & $2070 \pm 63(3)$ \\
\hline & & $\mathrm{K}-\mathrm{Ar}$ & Biotita & $2174 \pm 33(3)$ \\
\hline & & K-Ar & Anfibólio & $2082 \pm 51(3)$ \\
\hline & & $\mathrm{Rb}-\mathrm{Sr}$ & Rocha total & 2000 (4) (3), $2696 \pm 79(4)$ \\
\hline Ortognaisse Rio Campo Alegre & Granitoide & $\mathrm{Pb}-\mathrm{Pb}$ & Zircão & $2408 \pm 7$ a $2663 \pm 23(2)$ \\
\hline $\begin{array}{l}\text { Greenstone belt (Sequência } \\
\text { Mururé) }\end{array}$ & Rochas metassedimentares & $\mathrm{Pb}-\mathrm{Pb}$ & $\begin{array}{c}\text { Zircão } \\
\text { detrítico }\end{array}$ & $2833 \pm 7$ a $2975 \pm 14$ (5) \\
\hline \multicolumn{5}{|c|}{ Domínio Rio Maria } \\
\hline Granito tipo Xinguara & Leucogranito (Serra do Inajá) & $\mathrm{Pb}-\mathrm{Pb}$ & Zircão & $2875 \pm 11 \mathrm{Ma}(6) 2881 \pm 2 \mathrm{Ma}(7)$ \\
\hline Granito Xinguara & Leucogranito (área tipo) & $\mathrm{Pb}-\mathrm{Pb}$ & Zircão & $2865 \pm 1 \mathrm{Ma}(8)$ \\
\hline Granito tipo Mata Surrâo & Leucogranito (Pau D’arco) & $\mathrm{Pb}-\mathrm{Pb}$ & Zircão & $2868 \pm 5 \mathrm{Ma}(9)$ \\
\hline Granito tipo Mata Surrâo & Leucogranito (Marajoara) & $\mathrm{Pb}-\mathrm{Pb}$ & Zircão & $2871 \pm 7 \mathrm{Ma} \mathrm{(10)}$ \\
\hline Granito Mata Surrâo & Leucogranito (área tipo) & $\mathrm{Pb}-\mathrm{Pb}$ & Rocha total & $2872 \pm 10 \mathrm{Ma}(10)$ \\
\hline Trondhjemito Água Fria & Trondhjemito & $\mathrm{Pb}-\mathrm{Pb}$ & Zircão & $2864 \pm 21 \mathrm{Ma}(8,12)$ \\
\hline \multirow[t]{4}{*}{ Trondhjemito Mogno } & Granitoide & $\mathrm{U}-\mathrm{Pb}$ & Titanita & $2871 \pm ? \mathrm{Ma}(11)$ \\
\hline & Granitoide & $\mathrm{Pb}-\mathrm{Pb}$ & Zircão & $2857 \pm 13 \mathrm{Ma}(12)$ \\
\hline & Granitoide & $\mathrm{Pb}-\mathrm{Pb}$ & Zircão & $2900 \pm 21 \mathrm{Ma}(12)$ \\
\hline & Granitoide & $\mathrm{U}-\mathrm{Pb}$ & Zircão & $2965 \mathrm{Ma}(18)$ \\
\hline \multirow[t]{7}{*}{ Granodiorito Rio Maria } & Granodiorito & $\mathrm{U}-\mathrm{Pb}$ & Zircão & $2874+9 /-10 \mathrm{Ma}(13)$ \\
\hline & Granodiorito & $\mathrm{U}-\mathrm{Pb}$ & Zircão & $2872 \pm 5 \mathrm{Ma}(11)$ \\
\hline & Quartzo-diorito & $\mathrm{Pb}-\mathrm{Pb}$ & Zircão & $2878 \pm 4 \mathrm{Ma}(14)$ \\
\hline & Granodiorito (Serra do Inajá) & $\mathrm{Pb}-\mathrm{Pb}$ & Zircão & $2879 \pm 4 \mathrm{Ma}(11)$ \\
\hline & Granodiorito (Serra do Inajá) & $\mathrm{Pb}-\mathrm{Pb}$ & Zircão & $2877 \pm 6 \mathrm{Ma}(7)$ \\
\hline & Diorito (Serra do Inajá) & $\mathrm{Pb}-\mathrm{Pb}$ & Zircão & $2880 \pm 4 \mathrm{Ma}(7)$ \\
\hline & Granodiorito (Serra do Inajá) & $\mathrm{Pb}-\mathrm{Pb}$ & Zircão & $2881 \pm 8 \mathrm{Ma}(7)$ \\
\hline \multirow[t]{3}{*}{ Suíte Guarantã } & Granodiorito & $\mathrm{Pb}-\mathrm{Pb}$ & Zircão & $2868 \pm 5 \mathrm{Ma} \mathrm{(15)}$ \\
\hline & Leucogranito & $\mathrm{Pb}-\mathrm{Pb}$ & Zircão & $2870 \pm 5 \mathrm{Ma}(15)$ \\
\hline & Granito Guarantã & $\mathrm{Pb}-\mathrm{Pb}$ & Zircão & $2864 \pm 8 \mathrm{Ma}(9)$ \\
\hline \multirow[t]{2}{*}{ Suíte Guarantã } & Granito Guarantã & $\mathrm{U}-\mathrm{Pb}$ & Zircão & $2875 \pm 8 \mathrm{Ma}(18)$ \\
\hline & Granodiorito Trairão & $\mathrm{U}-\mathrm{Pb}$ & Zircão & $2872 \pm 7 \mathrm{Ma}(18)$ \\
\hline \multirow[t]{2}{*}{ Tonalito Mariazinha } & Tonalito & $\mathrm{U}-\mathrm{Pb}$ & Zircão & $2925 \pm 3 \mathrm{Ma} \mathrm{(16)}$ \\
\hline & Tonalito & $\mathrm{U}-\mathrm{Pb}$ & Zircão & $2918 \pm 13 \mathrm{Ma}(16)$ \\
\hline \multirow[t]{3}{*}{ Complexo Tonalítico Caracol } & Tonalito & $\mathrm{Pb}-\mathrm{Pb}$ & Zircão & $2948 \pm 5$ Ma (8) \\
\hline & Tonalito & $\mathrm{Pb}-\mathrm{Pb}$ & Zircão & $2636 \pm 3 \mathrm{Ma}(8)$ \\
\hline & Tonalito & $\mathrm{Pb}-\mathrm{Pb}$ & Zircão & $2924 \pm 2 \mathrm{Ma}(8)$ \\
\hline \multirow[t]{9}{*}{ Tonalito Arco Verde } & Tonalito & $\mathrm{U}-\mathrm{Pb}$ & Zircão & $2957+25$ / -21 Ma (13) \\
\hline & Tonalito & $\mathrm{Pb}-\mathrm{Pb}$ & Zircão & $2964 \pm 2 \mathrm{Ma}(17)$ \\
\hline & Tonalito & $\mathrm{Pb}-\mathrm{Pb}$ & Zircão & $2948 \pm 7 \mathrm{Ma}(7)$ \\
\hline & Tonalito & $\mathrm{Pb}-\mathrm{Pb}$ & Zircão & $2952 \pm 2 \mathrm{Ma}(16)$ \\
\hline & Tonalito & U-Pb & Zircão & $2936 \pm 13 \mathrm{Ma}(16)$ \\
\hline & Tonalito & $\mathrm{Pb}-\mathrm{Pb}$ & Zircão & $2926 \pm 2 \mathrm{Ma} \mathrm{(16)}$ \\
\hline & Tonalito & $\mathrm{U}-\mathrm{Pb}$ & Zircão & $2935 \pm 5 \mathrm{Ma} \mathrm{(16)}$ \\
\hline & Tonalito & $\mathrm{Pb}-\mathrm{Pb}$ & Zircão & $2937 \pm 3 \mathrm{Ma}(16)$ \\
\hline & Tonalito & $\mathrm{U}-\mathrm{Pb}$ & Zircão & $2973 \pm 11 \mathrm{Ma}(16)$ \\
\hline \multirow[t]{3}{*}{ Supergrupo Andorinhas } & Metagrauvaca & $\mathrm{U}-\mathrm{Pb}$ & Zircão & $2971 \pm 18 \mathrm{Ma}(13)$ \\
\hline & Metavulcânica félsica & $\mathrm{U}-\mathrm{Pb}$ & Zircão & $\begin{array}{c}2904+29 /-22 \mathrm{Ma} \mathrm{(10)} \\
2979 \pm 5 \mathrm{Ma}(11)\end{array}$ \\
\hline & Dacito & $\mathrm{U}-\mathrm{Pb}$ & Zircão & $3002 \pm 3 \mathrm{Ma}(17)$ \\
\hline
\end{tabular}

Fontes: (1) Barros et al. (2005); (2) Vasquez et al. (2007); (3) Tassinari e Basei (1980); (4) Cunha et al. (1981); (5) Monteiro et al. (2004); (6) Rolando e Macambira (2002); (7) Rolando e Macambira (2003); (8) Leite et al. (2004); (9) Almeida et al. (2008); (10) Althoff et al. (1998); (11) Pimentel e Machado (1994); (12) Macambira et al. (2000); (13) Macambira (1992); (14) Dall'Agnol et al. (1999); (15) Althoff et al. (2000); (16) Almeida et al. (2011); (17) Vasquez et al. (2008); (18) Almeida et al. (2010). 


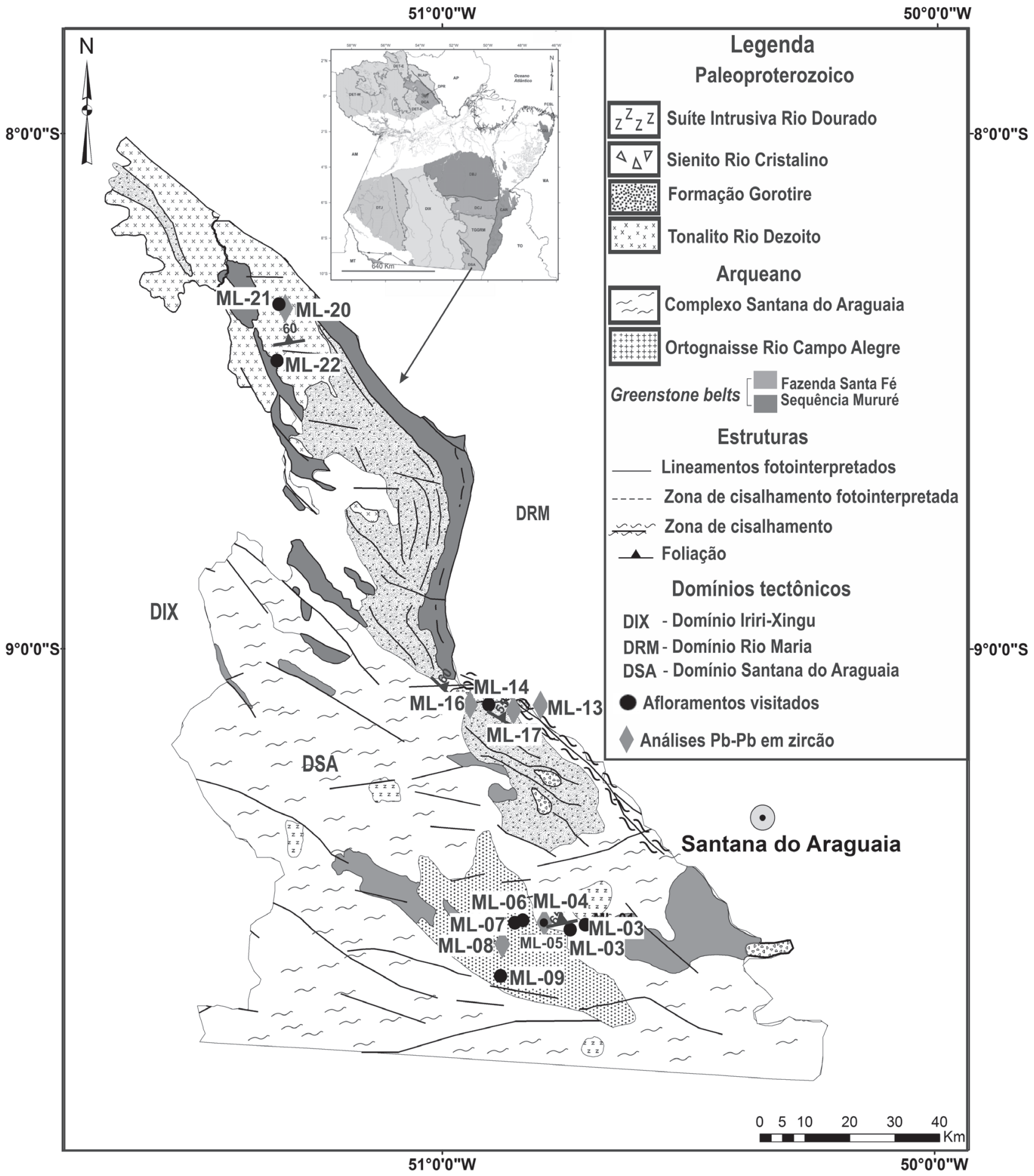

Figura 2. Mapa geológico simplificado do Domínio Santana do Araguaia, mostrando a localização dos afloramentos visitados e das amostras analisadas pelo método $\mathrm{Pb}-\mathrm{Pb}$ em zircão neste trabalho. Para mais detalhes sobre as idades obtidas neste trabalho, ver Tabela 3 (adaptado de Vasquez et al., 2008). 


\section{Unidades litoestratigráficas}

A Sequência Mururé localiza-se na porção norte do DSA, nos flancos da serra do Mururé (Figura 2), sendo constituída dominantemente de rochas metassedimentares. Predominam psamitos ricos em quartzo e feldspato (quartzito, metarenito e metarcóseo) e rochas com maior contribuição pelítica (metagrauvaca, metassiltito, biotita xisto quartzo-feldspático, filito e ardósia). Idades $\mathrm{Pb}-\mathrm{Pb}$ em zircões detríticos obtidas na Sequência Mururé variam entre $2833 \pm 7$ e $2975 \pm 14$ Ma (Monteiro et al., 2004; Tabela 1) e indicam idade máxima de sedimentação em torno de $2830 \mathrm{Ma}$.

A Sequência Fazenda Santa Fé (Figura 2) apresentase como faixas orientadas segundo a direção NW-SE. Ela é composta por rochas metamáficas e metassedimentares. As rochas metamáficas estão representadas por metabasaltos granofels e porfiríticos, plagioclásio-quartzo-actilonita granofels, quartzo-plagioclásio-tremolita xisto e quartzo -plagioclásio-actinolita xisto. Já as rochas metassedimentares são constituídas por quartzitos, biotita muscovita xisto, sericita quartzo xisto, muscovita biotita granofels, metarenito sericítico, metacalcário, formação ferrífera bandada e ardósia.

Segundo Vasquez et al. (2008), a unidade Ortognaisse Rio Campo Alegre ocorre na porção central do DSA (Figura 2), orientada segundo a direção NW-SE, e composta por leucognaisses granodioríticos e tonalíticos, granodioritos e tonalitos foliados, monzogranitos variando de gnaissificados a isotrópicos e migmatitos granodioríticos e monzograníticos. Cristais de zircão dessa unidade foram analisados pelo método de evaporação de $\mathrm{Pb}$, fornecendo valores entre $2408 \pm 7 \mathrm{e}$ $2663 \pm 23 \mathrm{Ma}$ (Vasquez et al., 2007; Tabela 1), sendo a maior idade interpretada como idade mínima de cristalização do protólito ígneo.

O Complexo Santana do Araguaia é a unidade de maior abrangência no DSA (Figura 2). Nele predominam monzogranitos, que variam de biotita monzogranitos a leucomonzogranitos, por vezes com duas micas. Biotita granodioritos e tonalitos são subordinados. O Complexo Santana do Araguaia ainda não foi datado, mas no Estado de Mato Grosso, em região que poderia representar o seu prolongamento para sul, foi obtida uma isócrona $\mathrm{Rb}-\mathrm{Sr}$ de referência em rocha total que indicou a idade de $2696 \pm 79$ Ma (Cunha et al., 1981; Tabela 1). Na mesma região, foram obtidas idades $\mathrm{K}-\mathrm{Ar}$ (minerais) e $\mathrm{Rb}-\mathrm{Sr}$ (isócrona de referência em rocha) paleoproterozoicas, variando entre 2170 e $2000 \mathrm{Ma}$ (Tassinari e Basei, 1980; Tabela 1), que, segundo Vasquez et al. (2008), refletem retrabalhamento durante o Ciclo Transamazônico.
O Tonalito Rio Dezoito, localizado na porção noroeste do DSA, ocorre como um batólito de forma alongada com direção NW-SE (Figura 2) e era, em trabalhos anteriores, mapeado como Complexo Xingu (Silva et al., 1974, Cunha et al., 1981, Faraco et al., 2004). Este corpo é composto por tonalitos, com subordinados granodioritos e monzogranitos, portadores de biotita e hornblenda, variando de isotrópicos a bandados. Segundo Vasquez et al. (2007, 2008), o retrabalhamento do DSA durante o Ciclo Transamazônico é confirmado pelo magmatismo granitoide paleoproterozoico de $2187 \pm 28 \mathrm{Ma}$ (Tabela 1), representado pelo Tonalito Rio Dezoito.

As rochas supracrustais formam sucessões pelíticas e psamíticas, que são correlacionadas com o Grupo Rio Fresco, e psamíticas quartzosas, correlacionadas com a Formação Gorotire, bem como derrames de rochas vulcânicas félsicas e depósitos piroclásticos associados que recobrem os granitoides do DSA (Figura 2).

Os granitos paleoproterozoicos, representados pela Suíte Intrusiva Rio Dourado e o Sienito Rio Cristalino (Figura 2), indicam o último evento magmático conhecido no DSA. Trata-se de manifestações plutônicas anorogênicas, de afinidade alcalina, sendo que a primeira tem características de granito tipo A, tendo sido datada em $1889 \pm 11 \mathrm{Ma}$ (Barros et al., 2005; Tabela 1).

\section{GEOLOGIA LOCAL}

O trabalho de campo realizado na região de Santana do Araguaia teve como foco os granitoides aflorantes por serem mais abundantes, com melhores exposições e na expectativa de serem mais fáceis de datar pelo método $\mathrm{Pb}-\mathrm{Pb}$ em zircão. Esses corpos são constituídos predominantemente por monzogranitos, granodioritos e tonalitos.

Os granitoides estudados, de um modo geral, são hololeucocráticos, exibem coloração variando de vermelho -acinzentado a cinza-esbranquiçado devido a variações na razão plagioclásio/feldspato potássico, com pontuações escuras que correspondem aos agregados de minerais máficos. Em geral, as rochas adotam textura fanerítica, média a grossa, variando de equigranular a inequigranular. Os corpos graníticos mostram-se pouco a moderadamente deformados, com estruturas planares bem mais desenvolvidas do que as lineares.

$\mathrm{Na}$ escala mesoscópica, são descritos bandamentos magmáticos rítmicos de direção E-W subverticais, caracterizados pela alternância de níveis ricos em minerais ferromagnesianos e níveis predominantemente quartzofeldspáticos. As rochas deformadas apresentam foliação penetrativa na escala regional, cuja trajetória tem direção E-W e mergulhos normalmente altos, formada pela 
orientação preferencial dos minerais e pela presença de finos níveis algo descontínuos, ora preferencialmente ricos em quartzo e feldspatos, ora com maior quantidade de minerais máficos. A foliação nas escalas regional e mesoscópica tem trajetória concordante com o que é observado regionalmente no DRM, também com trend E-W. No entanto, direções de foliações NW-SE, com mergulhos normalmente altos, ocorrem de forma localizada na porção centro-leste do DSA, evidenciando relações de truncamento e sugerindo que são mais novas do que as de direção E-W.

\section{Descrição dos litotipos}

Biotita monzogranito (amostras ML-01, 03, 05, $06,07,08$ e 09)

Ocorre na porção central do DSA (Figura 2) sendo, em geral, isotrópico (Figura 3A) e localmente apresentando bandamento composicional magmático, caracterizado pela alternância de níveis enriquecidos em quartzo e feldspatos e níveis máficos (Figura 3B). No geral, esse bandamento apresenta altos ângulos de mergulho e direção E-W. É comum a presença de enclaves de composição tonalíticagranodiorítica que correspondem a uma rocha mesocrática ( $46 \%$ máficos), de coloração cinza-escura, de aspecto anisotrópico com grau de deformação variando de moderado a forte e de textura equigranular hipidiomórfica fina.

Hornblenda-biotita granodiorito (amostras ML-16, 21 e 22)

Aflora na porção centro-leste e noroeste da área de estudo (Figura 2), tendo granulação média e cor cinza-esbranquiçada. No geral, o aspecto isotrópico é predominante, com uma leve orientação de origem magmática de biotita e hornblenda (Figura 3C).

\section{Enderbito (amostra $M L-13$ )}

Esse litotipo aflora na porção centro-leste da área e tem pouca expressão na topografia. No geral, a rocha apresenta aspecto isotrópico (Figura 3D), granulação grossa e cores que variam de verde a cinza-escuro.

\section{Biotita metagranodiorito (amostras ML-04 e 20)}

Afloram nas porções sul e norte da área (Figura 2), comumente na forma de lajedo. A foliação do tipo bandamento composicional consiste em uma trama planar regular. Essa estrutura se caracteriza pela alternância de níveis compostos de quartzo e plagioclásio e níveis máficos (Figura 3E). A disposição espacial da foliação pode ser observada como planos levemente ondulados, com mergulhos em torno de $65^{\circ}$ para $\mathrm{N}$ e em geral orientada segundo a direção E-W.

\section{Hornblenda-biotita metatonalito (amostras ML-14 e 17)}

Ocorrem na porção centro-leste da área (Figura 2). Em geral, as rochas apresentam uma foliação do tipo espaçada, anastomótica, definida pela alternância de níveis com biotita e anfibólio e níveis com quartzo e plagioclásio. Porfiroclastos de plagioclásio tipo sigma são rotacionados com sentido de movimentação sinistral. Os mesmos são contornados por cristais prismáticos alongados de anfibólio e biotita, imprimindo um aspecto porfiroclástico à rocha (Figura $3 \mathrm{~F}$ ). A disposição espacial da foliação possui direção NW-SE, com mergulhos em torno de $60^{\circ}$ para NE. É comum a presença de bandas de cisalhamento dúctil, com direção predominante NW-SE, de cinemática sinistral.

\section{PETROGRAFIA}

\section{Composição modal e classificação}

Foram realizadas análises modais em 14 amostras de granitoides que ocorrem na área (Tabela 2), sendo todas lançadas em diagramas Q-A-P e Q-(A+P)-M' (Figura 4). Seis amostras analisadas incidem no campo destinado aos monzogranitos, representados pelo tipo biotita monzogranito, cinco amostras incidem no campo dos granodioritos, representados pelos tipos biotita metagranodiorito e hornblenda-biotita granodiorito, e três no campo dos tonalitos, representados pelos tipos hornblenda-biotita metatonalito e enderbito.

\section{Aspectos petrográficos}

Os litotipos biotita metagranodiorito e hornblenda-biotita metatonalito apresentam características texturais muito semelhantes, notando-se apenas pequenas variações nas porcentagens de seus constituintes minerais (Tabela 2), sendo, por esse motivo, descritas conjuntamente. Da mesma forma serão descritas as unidades hornblenda-biotita granodiorito e enderbito. Porém, a unidade biotita monzogranito será descrita individualmente por apresentar características distintas dos demais litotipos.

\section{Biotita monzogranito}

Em termos microscópicos, esta unidade é caracterizada por mostrar textura granular hipidiomórfica (Figura 5A) que varia de fina a média. 

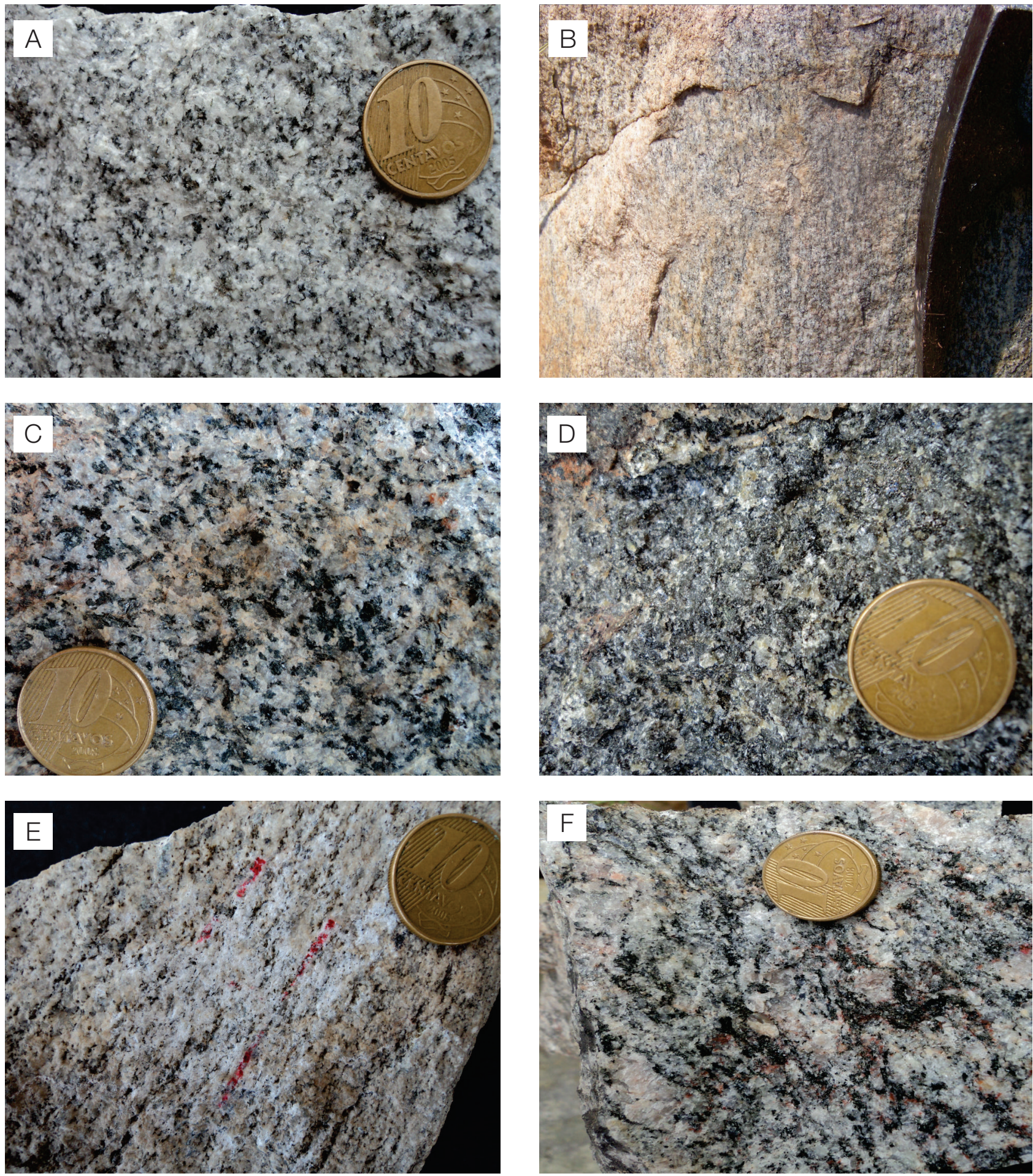

Figura 3. Aspectos texturais das rochas da região de Santana do Araguaia: (A) aspecto macroscópico mostrando estrutura isotrópica do biotita monzogranito; (B) acamamento magmático de alto ângulo no biotita monzogranito; (C) aparência macroscópica mostrando relativa orientação dos minerais máficos no hornblenda-biotita granodiorito; (D) estrutura isotrópica marcante no enderbito; (E) aspecto macroscópico do biotita metagranodiorito mostrando foliação discreta, caracterizada pela alternância de níveis compostos de quartzo e plagioclásio e níveis máficos; (F) foliação marcada pela orientação de biotita/ anfibólio contornando cristais de plagioclásio e desenhando foliação anastomótica no hornblenda-biotita metatonalito. 
Tabela 2. Composições modais de amostras das rochas estudadas da região de Santana do Araguaia (PA).

\begin{tabular}{|c|c|c|c|c|c|c|c|c|c|c|c|c|c|c|c|c|c|c|}
\hline \multirow{2}{*}{$\begin{array}{l}\text { Litotipo } \\
\text { Amostra/ } \\
\text { Mineral }\end{array}$} & \multicolumn{7}{|c|}{ Biotita monzogranito } & \multicolumn{3}{|c|}{$\begin{array}{c}\text { Biotita } \\
\text { metagranodiorito }\end{array}$} & \multicolumn{4}{|c|}{$\begin{array}{c}\text { Hornblenda-biotita } \\
\text { granodiorito }\end{array}$} & \multicolumn{3}{|c|}{$\begin{array}{l}\text { Hornblenda-biotita } \\
\text { metatonalito }\end{array}$} & \multirow{2}{*}{$\begin{array}{c}\text { Enderbito } \\
\qquad \frac{\frac{m}{1}}{\sum}\end{array}$} \\
\hline & 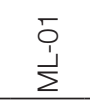 & $\begin{array}{l}\text { O) } \\
\stackrel{1}{\Sigma} \\
\sum\end{array}$ & 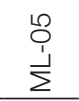 & $\stackrel{\substack{P \\
\dot{1}}}{\Sigma}$ & 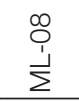 & $\begin{array}{l}\text { P } \\
\stackrel{1}{\Sigma} \\
\dot{\Sigma}\end{array}$ & $\frac{\frac{\pi}{0}}{\sum^{\mathbb{d}}}$ & $\stackrel{+}{\stackrel{1}{\Sigma}}$ & 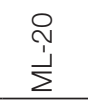 & $\begin{array}{l}\frac{\pi}{0} \\
\sum \\
\sum\end{array}$ & $\frac{\varphi}{\stackrel{0}{\Sigma}}$ & $\stackrel{\bar{N}}{\stackrel{\sim}{\Sigma}}$ & 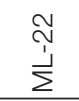 & $\begin{array}{l}\frac{\pi}{0} \\
\sum^{\mathbb{d}}\end{array}$ & $\frac{\nabla}{\stackrel{+}{\Sigma}}$ & $\frac{N}{\stackrel{N}{\Sigma}}$ & $\begin{array}{l}\frac{\pi}{0} \\
\frac{\mathbb{d}}{2}\end{array}$ & \\
\hline velut & 37,3 & 36,8 & 39,6 & 38 & 31,5 & 37,2 & 36,73 & 38,2 & 35,7 & 36,95 & 28,7 & 18,7 & 23,7 & 23,7 & 35,5 & 24,5 & 30,00 & 28,4 \\
\hline K-Feld & 23 & 25,5 & 25 & 30,6 & 28,5 & 23,7 & 26,05 & 14,9 & 12,9 & 13,9 & 13,4 & 16,2 & 11,7 & 13,77 & 1,5 & 1,5 & 1,50 & \\
\hline Plagioclásio & 33,6 & 33 & 31 & 25,5 & 34,8 & 32,4 & 31,72 & 37,9 & 45,9 & 41,9 & 35,9 & 47,4 & 51,9 & 45,07 & 35,7 & 59 & 47,35 & 40,4 \\
\hline Hornk & - & - & - & - & - & - & x & - & - & $x$ & 7,8 & 16,4 & 6,5 & 10,23 & 9 & 6 & 7,50 & - \\
\hline Biotita & 4,2 & 3,7 & 2,5 & 4,3 & 4,4 & 5,1 & 4,03 & 9,2 & 5,3 & 7,25 & 13,1 & 4 & 4,6 & 7,23 & 9 & 8,3 & 8,65 & 11,9 \\
\hline $\begin{array}{l}\text { Clinopiroxênio } \\
\text { (diopsídio) }\end{array}$ & - & - & - & - & - & - & $x$ & - & - & $x$ & - & - & - & $x$ & - & - & $x$ & 2,5 \\
\hline $\begin{array}{l}\text { Ortopir } \\
\text { (hipers }\end{array}$ & - & - & - & - & - & - & $x$ & - & - & $x$ & - & - & - & $x$ & - & - & $x$ & 11,2 \\
\hline Opac & 0,5 & $x$ & 0,4 & 0,6 & 0,1 & 0,7 & 0,46 & $x$ & $x$ & $x$ & 0,1 & 0,3 & 0,2 & 0,20 & 0,1 & 0,5 & 0,30 & 0,6 \\
\hline Zircã & $x$ & $x$ & 0,2 & 0,1 & $x$ & $x$ & 0,15 & $x$ & $x$ & $x$ & 0,1 & 0,2 & 0,3 & 0,20 & $x$ & $x$ & $x$ & \\
\hline Titan & 0,2 & $x$ & - & - & - & 0,1 & 0,15 & - & - & $x$ & - & - & - & $x$ & $x$ & $x$ & $x$ & . \\
\hline Apatita & 0,1 & $x$ & 0,3 & $x$ & $x$ & $x$ & 0,20 & $x$ & $x$ & $x$ & $x$ & $x$ & $x$ & $x$ & $x$ & $x$ & $x$ & $x$ \\
\hline Allani & $x$ & - & 0,4 & 0,1 & 0,2 & 0,3 & 0,25 & 0,1 & - & 0,1 & - & - & - & $x$ & 0,6 & $x$ & 0,60 & - \\
\hline Epídoto & 0,1 & $x$ & $x$ & 0,6 & $x$ & 0,1 & 0,27 & $x$ & $x$ & $x$ & $x$ & $x$ & $x$ & $x$ & $x$ & $x$ & $x$ & - \\
\hline Clorita & $x$ & $x$ & $x$ & $x$ & $x$ & $x$ & $x$ & $x$ & $x$ & $x$ & $x$ & $x$ & $x$ & $x$ & $x$ & $x$ & $x$ & - \\
\hline Máficos & 4,7 & 3,7 & 2,9 & 4,9 & 4,5 & 5,8 & 4,42 & 9,2 & 5,3 & 7,25 & 21 & 16,7 & 11,3 & 16,33 & 26,5 & 15,2 & 20,85 & 26,2 \\
\hline$A+P$ & 56,6 & 58,5 & 56 & 56,1 & 63,3 & 56,1 & 57,77 & 52,8 & 58,8 & 55,8 & 49,3 & 63,6 & 63,6 & 58,83 & 37,2 & 60,5 & 48,85 & 45,2 \\
\hline Feldsp & 24,49 & 26,76 & 26,15 & 32,52 & 30,06 & 25,40 & 27,56 & 16,37 & 13,65 & 15,01 & 17,18 & 19,68 & 13,40 & 16,76 & 2,06 & 1,76 & 1,91 & 6,52 \\
\hline Plagio & 35,78 & 34,63 & 32,43 & 27,10 & 36,71 & 34,73 & 33,56 & 41,65 & 48,57 & 45,11 & 46,03 & 57,59 & 59,45 & 54,36 & 49,11 & 69,41 & 59,26 & 54,89 \\
\hline Quartzo* & 39,72 & 38,61 & 41,42 & 40,38 & 33,23 & 39,87 & 38,87 & 41,98 & 37,78 & 39,88 & 36,79 & 22,72 & 27,15 & 28,89 & 48,83 & 28,82 & 38,83 & 38,59 \\
\hline $\mathrm{N}^{\circ}$ de pontos & 2000 & 2000 & 200 & 2000 & 2000 & 2000 & 2000 & 2000 & 2000 & 2000 & 2000 & 2000 & 2000 & 2000 & 2000 & 2000 & 2000 & 2000 \\
\hline
\end{tabular}

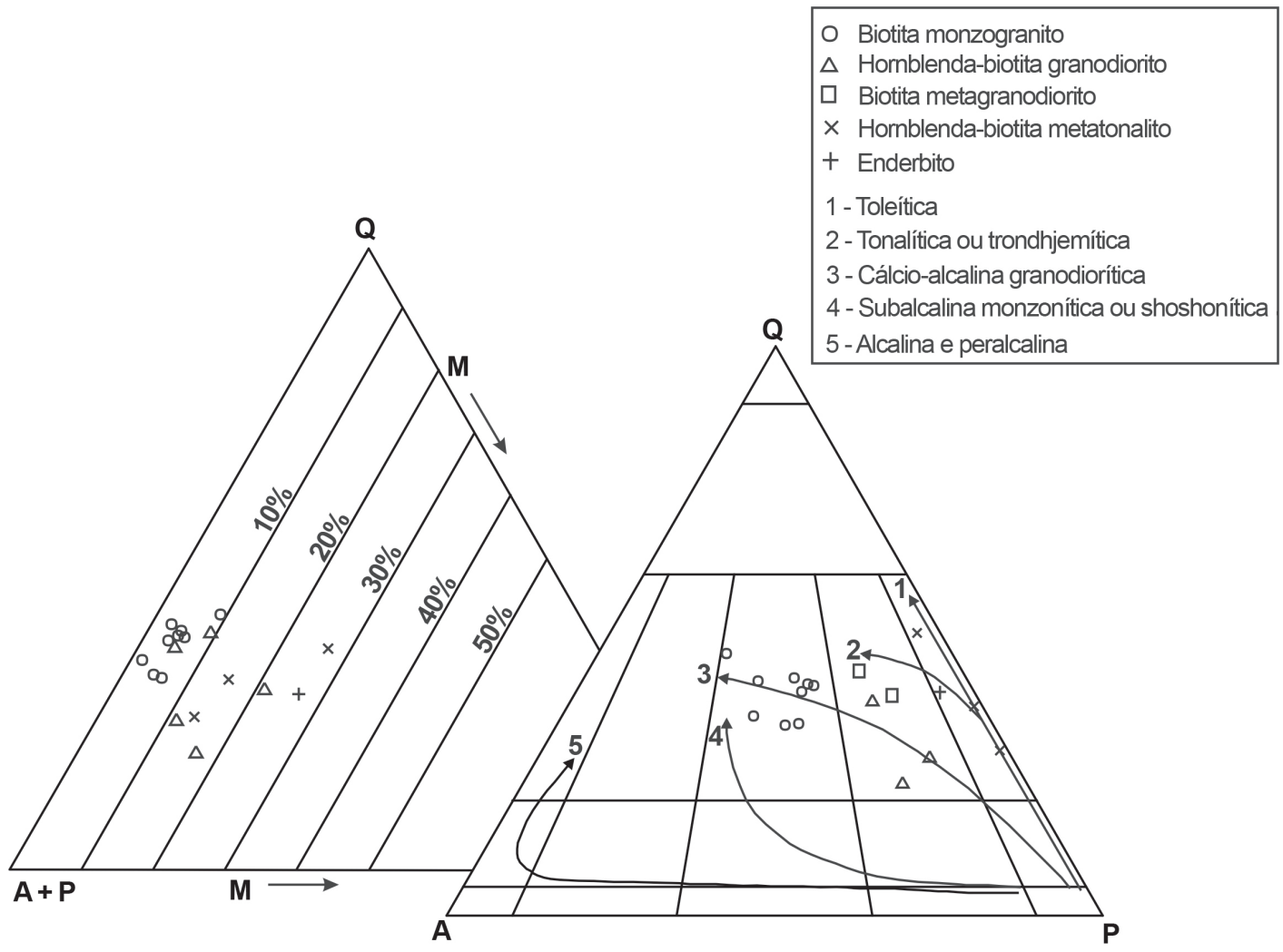

Figura 4. Diagramas modais Q-A-P e Q-(A+P)-M' de Streckeisen (1976) para as rochas estudadas. Os itens 1 a 5 são trends evolutivos de séries granitoides (Lameyre e Bowden, 1982; Bowden et al., 1984). 

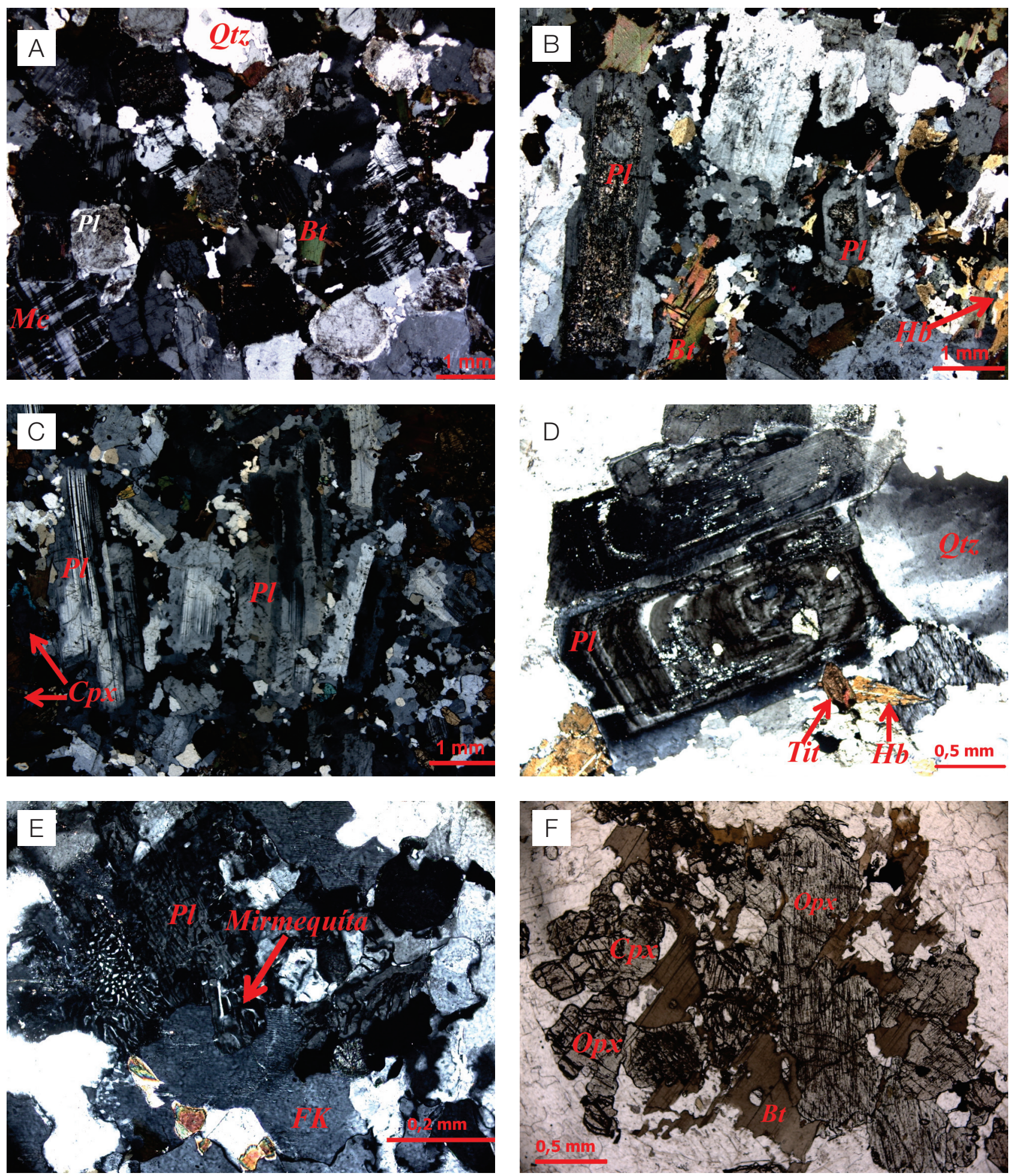

PI: Plagioclásio; FK: Feldspato potássico; Bt: Biotita; Qtz: Quartzo; Hb: Hornblenda; Tit: Titanita; Cpx: Clinopiroxênio; Opx: Ortopiroxênio.

Figura 5. Aspecto petrográfico de rochas de Santana do Araguaia: (A) textura granular hipidiomórfica no biotita monzogranito; (B) hornblenda-biotita granodiorito com cristais de plagioclásio com orientação marcante e núcleos descalcificados; (C) orientação subparalela de fenocristais de plagioclásio no enderbito; (D) cristais de plagioclásio com zoneamento oscilatório no hornblenda-biotita granodiorito; (E) cristais de plagioclásio em contato com feldspato potássico pertítico, com mirmequitas associadas a esse contato no enderbito; (F) cristais de biotita e piroxênio no enderbito. 
O plagioclásio ocorre como cristais subédricos a euédricos, normalmente milimétricos, podendo alcançar $3 \mathrm{~mm}$. Apresenta maclamento do tipo albita com mais frequência, enquanto o Carlsbad é mais raro. São comuns contornos irregulares a regulares e contatos retos com os minerais de quartzo e biotita. Na maioria dos cristais, as maclas são apenas parcialmente visíveis devido à forte alteração dos mesmos, o que dificulta determinar a composição deste mineral. Em geral, os cristais apresentam-se saussuritizados, tendo como principais produtos de alteração sericita e epídoto.

Os cristais de microclínio são, em geral, subédricos e localmente euédricos; os cristais variam de submilimétricos até em torno de $5 \mathrm{~mm}$, apresentando contatos irregulares e raramente retos e mostrando-se com inclusões de quartzo, plagioclásio e, em menor abundância, allanita, o que lhes confere um aspecto poiquilítico. O maclamento albita-periclina está presente de forma parcial ou total em muitos cristais. É comum a presença da textura mimerquítica.

Os cristais de quartzo apresentam-se dispostos aleatoriamente e são subédricos, inequigranulares, com tamanho variando de $0,1 \mathrm{a} 1,3 \mathrm{~mm}$, com contornos regulares a irregulares, reentrantes e por vezes regulares entre si.

Os cristais de biotita são subautomórficos inequigranulares com tamanhos variando de 0,2 a $0,5 \mathrm{~mm}$. Apresentam contornos regulares e irregulares, contatos retos entre si e com os demais. É comum a ocorrência de biotita formando agregados máficos com a titanita e opacos. Localmente, há transformação de biotita em clorita e inclusões de zircão, formando halos pleocroicos. Os minerais acessórios compreendem titanita, opacos, zircão, apatita e allanita.

\section{Hornblenda-biotita granodiorito e enderbito}

Essas unidades apresentam uma leve orientação de seus cristais, principalmente plagioclásio, anfibólio e biotita, perceptível principalmente em lâmina delgada (Figuras 5B e 5C). De acordo com Vigneresse et al. (1996), minerais com forma prismática, tais como feldspatos e minerais máficos, quando imersos em magma submetido a fluxo laminar, tendem a sofrer rotação e alinhamento paralelo à direção de fluxo, que origina os planos de acamamento rítmico.

No enderbito, o plagioclásio ocorre como minerais subédricos a euédricos, normalmente milimétricos, podendo alcançar $6 \mathrm{~mm}$. Apresenta maclamento do tipo albita, com orientação preferencial marcante, porém sem características deformacionais, e é isento de alteração (Figura 5C). Já no hornblenda-biotita granodiorito, há indícios de zoneamento normal no plagioclásio, pois alguns cristais mostram maior alteração na parte central, sugerindo núcleo mais cálcico (Figura 5B), além de cristais com zoneamento oscilatório marcante (Figura 5D), mirmequitas são comuns no contato entre plagioclásio e feldspato potássico pertítico no enderbito (Figura 5E). Em ambos os litotipos, os contornos e contatos entre esses cristais e os demais costumam ser regulares. É menos frequente que sejam irregulares.

O feldspato potássico é pertítico com lamelas finas do tipo fita ou string (Smith, 1974). É anédrico a subédrico, tem granulação média e contatos irregulares com os demais minerais. No enderbito, são comuns inclusões de apatita, ortopiroxênio e clinopiroxênio, o que dá um aspecto poiquilítico. Esses cristais apresentam com grande frequência textura mimerquítica, por vezes formam agregados com cristais de biotita de granulação fina.

Os cristais de quartzo apresentam-se dispostos aleatoriamente e entre os cristais maiores de plagioclásio. São subautomórficos a xenomórficos, de granulação fina a média e exibem extinção reta, por vezes ondulante, com contornos regulares a irregulares.

Os cristais de biotita (Figura 5F) são subautomórficos a automórficos, de granulação fina a média $(0,2-$ $1,5 \mathrm{~mm}$ ), com pleocroísmo variando entre amarelo-pálido $(\mathrm{X}=\mathrm{Y})$ a marrom-escuro $(\mathrm{Z})$. Apresentam contornos regulares e irregulares, contatos retos entre si e com os demais. É comum a ocorrência de biotita formando agregados com cristais de hornblenda no hornblenda-biotita granodiorito, imprimindo uma moderada orientação preferencial desses cristais, além de kink bands.

$\mathrm{O}$ anfibólio (Figura 5B), pelo ângulo de extinção em torno de $23^{\circ}, 2 \mathrm{~V}$ em torno de $65^{\circ}$ e sinal ótico biaxial negativo, é considerado hornblenda. Esse mineral apresenta uma orientação preferencial formando níveis com biotita. Os cristais de hornblenda são euédricos a subédricos, de granulação fina a média. $\mathrm{O}$ seu pleocroísmo varia de verde-claro (x), verde-escuro (y) e verde-oliva a verde-azulado (z). Contornos e contatos irregulares e retos com a biotita também são observados, apresentando ainda maclamento simples e restos de piroxênio em seu núcleo.

O ortopiroxênio, por apresentar extinção paralela, $2 \mathrm{~V}$ em torno de $63^{\circ}$ e sinal óptico biaxial negativo, é interpretado como hiperstênio, é subédrico a euédrico, normalmente milimétrico, podendo alcançar $4 \mathrm{~mm}$. Esses cristais apresentam baixas cores de interferência, geralmente amarelo-pálido. Os seus contornos e contatos são regulares, com contatos retos com os cristais de quartzo e biotita e entre si. É comum estarem associados com biotita e clinopiroxênio (diopsídio) (Figura 5F). Geralmente estão em maior proporção que 
o clinopiroxênio (Tabela 2). Localmente percebe-se uma orientação desses minerais, junto com biotita, diopsídio e plagioclásio.

O clinopiroxênio pelo ângulo de extinção em torno de $38^{\circ}, 2 \mathrm{~V}$ em torno de $58^{\circ}$ e sinal óptico biaxial positivo, é interpretado como diopsídio (Figura 5F), ocorre como cristais subédricos a euédricos, normalmente milimétricos, podendo alcançar $3 \mathrm{~mm}$. Apresentam altas cores de interferência, como azul intenso, contornos e contatos regulares e menos frequentemente irregulares, localmente é perceptível uma orientação desse mineral, junto com biotita, ortopiroxênio e plagioclásio.

Os minerais acessórios mais comuns nessas rochas são opacos, zircão e apatita.
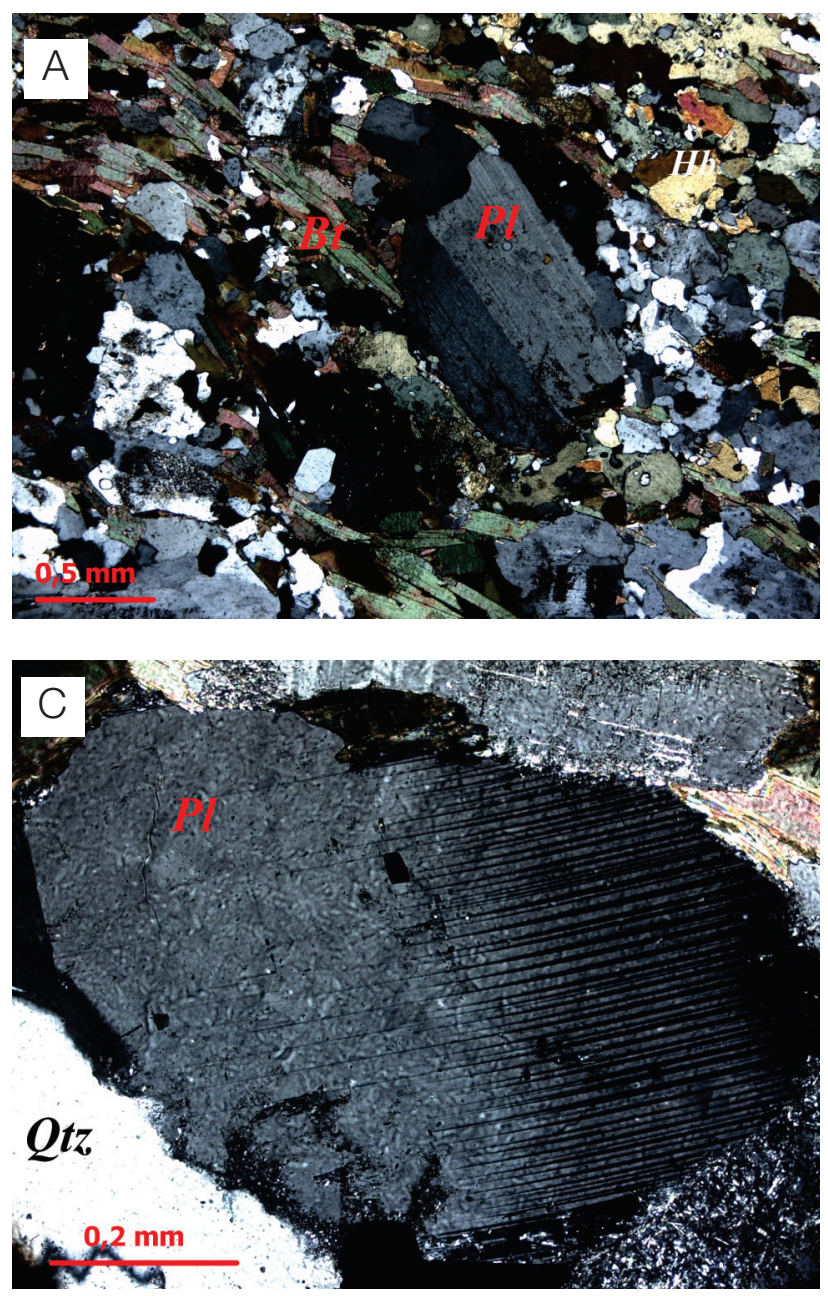

PI: Plagioclásio; Bt: Biotita; Qtz: Quartzo; Hb: Hornblenda.

\section{Biotita metagranodiorito e hornblenda-biotita metatonalito}

A textura característica dessas rochas é granular hipidiomórfica média, modificada em diferentes intensidades pela deformação que varia desde discreta, afetando apenas o quartzo, até intensa, gerando texturas protomiloníticas (Figura 6A), com forte recristalização do quartzo e formação de subgrãos (Figura 6B). No plagioclásio, são comuns maclas lenticulares (Figura 6C) e geração de fenoclastos prismáticos, por vezes ovalados, que são contornados pela matriz fina proveniente de recristalização e cominuição dos grãos primitivos, imprimindo um aspecto orientado à rocha (Figura 6A).
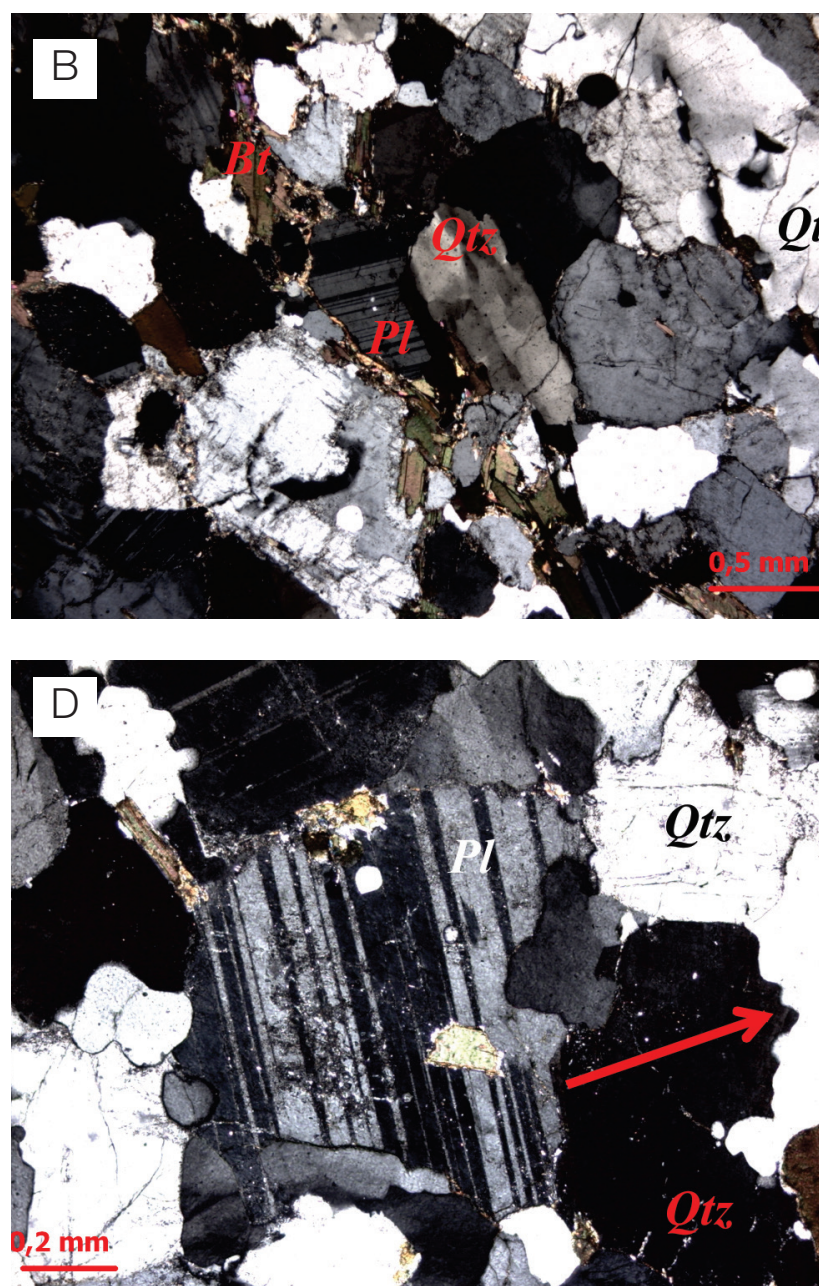

Figura 6. (A) Aspecto microscópico do hornblenda-biotita metatonalito mostrando a orientação dos cristais de biotita e hornblenda contornando porfiroclasto de plagioclásio. (B) Orientação discreta dos minerais máficos, marcando a foliação do biotita metagranodiorito, além de cristais de quartzo recristalizado em forma de subgrãos. (C) Cristal de plagioclásio com terminações lenticulares de suas maclas, originadas por processo deformacional no hornblenda-biotita metatonalito. (D) Cristal de plagioclásio, com terminações abruptas de suas maclas, sugerindo origem ígnea, e cristais de quartzo com contato suturado-serrilhado indicado pela seta em vermelho no biotita metagranodiorito. 
A foliação nessas rochas é definida pela forte orientação preferencial dos minerais e pela presença de finos níveis descontínuos, por vezes com níveis preferencialmente ricos em quartzo e feldspatos, ora com maior quantidade de minerais máficos. Porém, é possível encontrar cristais não deformados, com características ígneas preservadas, principalmente no plagioclásio, que apresenta maclas com terminações abruptas (Figura 6D), sugerindo origem ígnea, além de zoneamento oscilatório.

O plagioclásio é dominantemente hipidiomórfico e apresenta dimensões superiores às do quartzo. Exibe contatos irregulares e subordinadamente retilíneos entre si. Mostra-se alterado para sericita e epídoto, o que mascara as suas feições originais. Há indícios de zoneamento normal, pois alguns cristais mostram maior alteração na parte central, sugerindo núcleo mais cálcico. Localmente, são vistas mirmequitas nas bordas dos cristais de plagioclásio em contato com feldspato potássico. A deformação em alguns cristais se manifesta como uma discreta a forte extinção ondulante, além de maclas encurvadas e lenticulares.

O microclínio ocorre como cristais xenomórficos, de granulação fina a média, com contatos ondulantes com os cristais de quartzo e retilíneos entre si. São tardios, preenchendo interstícios, e pobres em lamelas pertíticas. Apresentam inclusões de plagioclásio e biotita.

O quartzo apresenta-se em cristais subédricos, mostra contatos irregulares e sinuosos entre si, ondulados com os cristais de plagioclásio e geralmente retilíneos com a biotita. O grau de deformação desses cristais é variado. Por vezes, eles apresentam-se subédricos e sem deformação aparente ou levemente estirados acompanhando a direção da foliação, e, em outras, deformados com forte extinção ondulante e formação de subgrãos e novos grãos submilimétricos nas suas bordas e contatos serrilhado-suturados entre si (Figura 6D).

A biotita ocorre como lamelas de granulação fina a média, hipidiomórficas, em geral orientadas, definindo a foliação da rocha. Forma agregados com cristais de titanita e opacos e apresenta-se como inclusão em cristais de plagioclásio e feldspato potássico. Localmente, é substituída parcial a totalmente por clorita, que se posiciona preferencialmente ao longo dos seus planos de clivagem. Extinção ondulante e kink bands são observadas como produto da deformação, algumas em forma de peixe, marcando deformação de caráter sinistral.

$\mathrm{O}$ anfibólio, pelo ângulo de extinção em torno de $23^{\circ}, 2 \mathrm{~V}$ em torno de $65^{\circ}$ e sinal óptico biaxial negativo, é interpretado como hornblenda. Os cristais apresentam uma orientação preferencial, formando níveis com biotita que se intercalam com outros mais ricos em quartzo, feldspato potássico e plagioclásio. Tais níveis por vezes são descontínuos. Os cristais de hornblenda são subédricos subautomórficos a xenomórficos, de granulação fina a média. O seu pleocroísmo varia de verde-claro $(\mathrm{X})$, verde-escuro $(\mathrm{Y})$ e verde-oliva a verde-azulado $(\mathrm{Z})$. Contornos e contatos irregulares e retos com a biotita também são observados. Os minerais acessórios dessas unidades compreendem titanita, opacos, apatita e zircão.

\section{GEOCRONOLOGIA POR EVAPORAÇÃO DE PB EM MONOCRISTAIS DE ZIRCÃO}

O estudo petrográfico realizado neste trabalho permitiu selecionar amostras representativas de cada litotipo, a fim de que fossem determinadas suas idades de cristalização pelo método de evaporação de $\mathrm{Pb}$. Assim, foram analisados cristais de zircão das amostras ML-04, ML-20, ML-17, ML-08, ML-16 e ML-13, representativas dos litotipos biotita metagranodiorito, hornblenda-biotita metatonalito, biotita monzogranito, hornblenda-biotita granodiorito e enderbito, respectivamente.

\section{Métodos analíticos}

As análises pelo método evaporação de $\mathrm{Pb}$ foram realizadas no Laboratório de Geologia Isotópica (Pará-Iso) da Universidade Federal do Pará. Para a obtenção dos cristais de zircão, foram seguidos os procedimentos habituais de trituração, pulverização, lavagem, peneiramento, separação magnética no separador Frantz, elutriação e separação em bromofórmio. A seleção dos melhores grãos foi realizada com o auxílio de lupa binocular, dando preferência para os cristais sem evidências de metamitização, sem inclusões ou fraturas. Para a análise dos cristais de zircão, seguiu-se o método de Kober (1987), pelo qual o cristal é analisado no estado sólido e as idades ${ }^{207} \mathrm{~Pb} /{ }^{206} \mathrm{~Pb}$ obtidas podem ser consideradas como idades "máximas" ou como idades representativas da cristalização do mineral. Os cristais foram depositados em filamentos de Re, introduzidos em um espectrômetro de massa Finnigan MAT 262 e submetidos a etapas de evaporação a diferentes temperaturas $\left(1450^{\circ} \mathrm{C}, 1500^{\circ} \mathrm{C}\right.$ e $\left.1550^{\circ} \mathrm{C}\right)$. Outro filamento recebe o $\mathrm{Pb}$ evaporado e, posteriormente, a cada evaporação, é aquecido para ionizar os isótopos de $\mathrm{Pb}$ nele depositados. As idades obtidas nas diferentes etapas de evaporação podem apresentar diferentes valores, sendo que, normalmente, observa-se um aumento nas idades no sentido das etapas de mais alta temperatura. Quando isso ocorre, são consideradas apenas as idades obtidas nas temperaturas mais altas, pois, neste caso, o $\mathrm{Pb}$ analisado é proveniente das porções mais internas do cristal de zircão, que 
são consideradas de maior capacidade de retenção de $\mathrm{Pb}$. $\mathrm{O}$ cálculo da idade é feito após correções do $\mathrm{Pb}$ comum inicial, baseadas no modelo de evolução do Pb em estágio duplo (Stacey e Kramers, 1975) para os blocos de razões isotópicas com razões ${ }^{204} \mathrm{~Pb} /{ }^{206} \mathrm{~Pb}$ acima de 0,0004 , a fim de reduzir a interferência de $\mathrm{Pb}$ comum. Após tratamento dos dados, segundo critérios estabelecidos por Gaudette et al. (1998), os resultados finais são apresentados com desvios de $2 \sigma$.

\section{Resultados analíticos}

\section{Biotita metagranodiorito}

Duas amostras desse litotipo (ML-04 e ML-20) foram selecionadas para análise, sendo a amostra ML-04 da porção sul e a ML-20 da porção norte da área. Os cristais de zircão selecionados da amostra ML-04 são prismáticos, bipiramidais, semitransparentes e com cores que variam de castanho-claro a castanho-escuro. Mostram poucas inclusões, fraturas e evidências de metamitização, além de apresentarem zoneamento oscilatório sugerindo uma origem ígnea (Figura 7A). Um conjunto de quatro cristais dessa amostra forneceu idade de $3066 \pm 3$ Ma (Tabela 3; Figura 7A). Três outros cristais de zircão forneceram idade de $3137 \pm 8 \mathrm{Ma}$ (Tabela 3, Figura 7B) que, provavelmente, representam cristais herdados. Os cristais de zircão da amostra ML-20 são prismáticos, com suas bordas corroídas, por vezes arredondadas, apresentando cor castanho-escura, refletindo possivelmente um maior grau de metamitização (Figura 7C). De um conjunto de 35 cristais selecionados, apenas 3 forneceram sinal de $\mathrm{Pb}$ suficiente para o cálculo da idade média, que resultou no valor de $2830 \pm 13 \mathrm{Ma}$ (Tabela 3, Figura 7C).

\section{Hornblenda-biotita metatonalito}

Os cristais de zircão desse litotipo (ML-17) são prismáticos, bipiramidais, com as bordas ligeiramente arredondadas, cor marrom, por vezes pálidos, variando de translúcidos a transparentes, e apresentam poucas inclusões e fraturas em seus núcleos (Figura 7D). De um conjunto de 18 cristais selecionados, apenas 4 forneceram sinal de $\mathrm{Pb}$ suficiente para a análise isotópica que produziu uma idade média de $2852 \pm 2 \mathrm{Ma}$ (Tabela 3; Figura 7D).

\section{Biotita monzogranito}

Os cristais de zircão selecionados da amostra ML-08 são prismáticos, bipiramidais, com cores que variam de marrom-claro a marrom-escuro, por vezes rosados, transparentes, com poucas inclusões e fraturas.
Apresentam núcleos mais escuros que as bordas. Os resultados isotópicos não indicaram idade precisa, e sim valores dispersos, que variaram entre 2599 e $2424 \mathrm{Ma}$ (Tabela 3), razão pela qual não foram apresentados em diagrama. Tal dispersão de idade pode ser explicada devido à falta de sinal de $\mathrm{Pb}$ suficiente para se chegar a uma idade precisa, pois foram evaporados aproximadamente 50 grãos de zircões, mas eles não forneceram sinal de $\mathrm{Pb}$ suficiente para a análise isotópica e fechamento de idade média, devido possivelmente a processos de perda de chumbo por metamitização.

\section{Hornblenda-biotita granodiorito}

Os cristais de zircão selecionados da amostra ML-16 são prismáticos, bipiramidais, apresentam bordas levemente arredondadas, poucas inclusões e fraturas, com cores que variam de castanho-claro com porções incolores a transparentes (Figura 7E). Dos grãos analisados, apenas quatro cristais emitiram sinal de $\mathrm{Pb}$ suficiente para as medições isotópicas. Tais cristais forneceram idade média de $1990 \pm 7$ Ma (Tabela 3; Figura 7E).

\section{Enderbito}

A amostra datada desse litotipo, ML-13, apresenta cristais de zircão prismáticos, bipiramidais, por vezes com formas arredondadas; variam de translúcidos a semitransparentes, além de apresentarem inclusões e fraturas em seus núcleos (Figura 7F). De um conjunto de 14 grãos selecionados, 6 emitiram sinal de $\mathrm{Pb}$ suficiente para o cálculo da idade, fornecendo idade média de $1989 \pm 4$ Ma (Tabela 3; Figura $7 \mathrm{~F})$.

\section{DISCUSSÃO E INTERPRETAÇÃO DOS RESULTADOS}

Uma discussão acerca da evolução tectônica da região de Santana do Araguaia e sua relação com o adjacente Domínio Rio Maria necessariamente tem que levar em conta os aspectos deformacionais e magmáticos das rochas que lá ocorrem, além de uma escala temporal calibrada.

Em relação aos aspectos deformacionais e magmáticos, o padrão de estruturas dos granitoides da região estudada sugere que a deformação foi imposta depois da completa cristalização dos mesmos e que a evolução estrutural das rochas parece ter sido controlada pelos mesmos mecanismos nos diferentes minerais. Entretanto, observa-se que existe uma diferença no momento em que cada mineral responde aos esforços e, consequentemente, na impressão das microestruturas. Nos cristais de quartzo, feldspato potássico e 

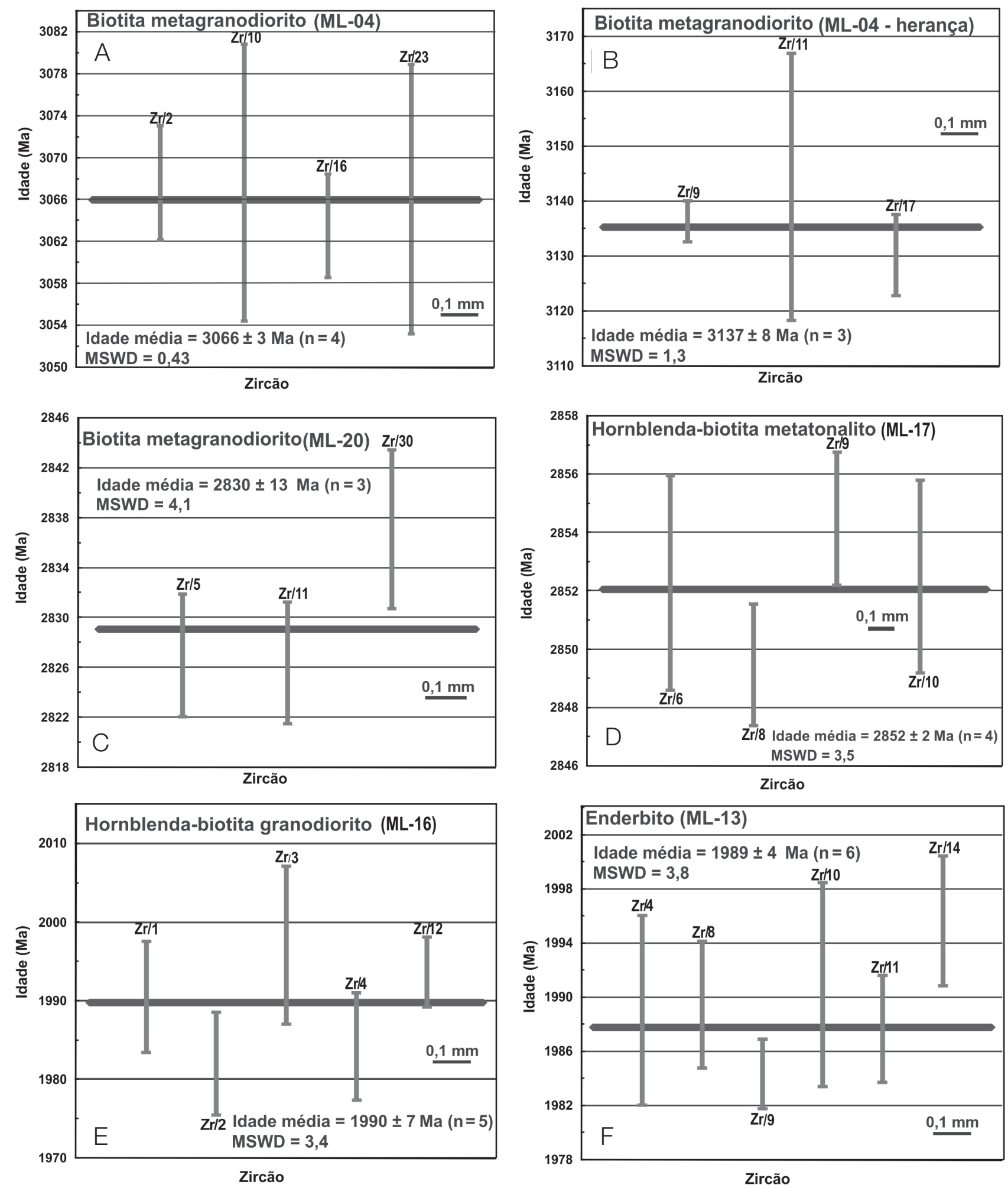

MSWD: Mean square weighted deviation.

Figura 7. Diagramas apresentando resultados obtidos pelo método de evaporação de Pb de zircão para as rochas estudadas da região de Santana do Araguaia, Pará. 
plagioclásio, foi verificada uma evolução microestrutural semelhante, caracterizada pela presença das seguintes feições: extinção ondulante; bandas de deformação; formação de subgrãos; novos grãos; extinção ondulante de novos grãos. Entretanto, vale destacar que essas feições, que denotam uma sequência de eventos, ocorrem mais prontamente nos cristais de quartzo, ou seja, um mineral que se deforma sob condições menos

Tabela 3. Resultados das análises isotópicas de Pb dos cristais de zircão das amostras de rochas da região de Santana do Araguaia pelo método de evaporação de $\mathrm{Pb}$ de zircão.

\begin{tabular}{|c|c|c|c|c|c|c|c|c|c|}
\hline Amostra/Zircão & Razões* & ${ }^{204} \mathrm{~Pb} /{ }^{206} \mathrm{~Pb}$ & $\pm 2 \sigma$ & $\left({ }^{208} \mathrm{~Pb} / 206 \mathrm{~Pb}\right) \mathrm{c}$ & $\pm 2 \sigma$ & $\left({ }^{207} \mathrm{~Pb} / 206 \mathrm{~Pb}\right) \mathrm{c}$ & $\pm 2 \sigma$ & Idade (Ma) & $\pm 2 \sigma$ \\
\hline \multicolumn{10}{|c|}{ Biotita metagranodiorito (porção sul) - ML-04 } \\
\hline ML-04/2 & $36 / 36$ & 0,000094 & 0,000007 & 0,0853 & 0,00119 & 0,23221 & 0,0008 & 3067,6 & 5,5 \\
\hline ML-04/10 & $8 / 8,0$ & 0,000181 & 0,00007 & 0,20989 & 0,00237 & 0,23221 & 0,00192 & 3067,7 & 13,2 \\
\hline ML-04/16 & $26 / 34$ & 0,000105 & 0,000006 & 0,15587 & 0,00215 & 0,23162 & 0,00072 & 3063,6 & 5 \\
\hline ML-04/23 & $34 / 34$ & 0,000111 & 0,000008 & 0,11613 & 0,00453 & 0,23199 & 0,00187 & 3066,1 & 12,9 \\
\hline Total & 104/112 & & & & & Idade média & & $3066 \pm 3$ & \\
\hline \multicolumn{10}{|c|}{ Biotita metagranodiorito (herança) - ML-04 } \\
\hline ML-04/9 & 40/62 & 0,000117 & 0,00001 & 0,13989 & 0,00087 & 0,24245 & 0,00059 & 3136,4 & 3,8 \\
\hline ML-04/11 & $6 / 46$ & 0,000347 & 0,000266 & 0,15347 & 0,00819 & 0,24344 & 0,00083 & 3142,8 & 5,3 \\
\hline ML-04/17 & $8 / 8$ & 0,000077 & 0,000086 & 0,1104 & 0,00338 & 0,24153 & 0,00113 & 3130,3 & 7,4 \\
\hline Total & $54 / 116$ & & & & & Idade média & & $3137 \pm 8$ & \\
\hline \multicolumn{10}{|c|}{ Biotita metagranodiorito (porção norte) - ML-20 } \\
\hline ML-20/5 & $34 / 42$ & 0,000321 & 0,000012 & 0,09838 & 0,00448 & 0,20004 & 0,00063 & 2826,9 & 5,1 \\
\hline ML-20/11 & $30 / 68$ & 0,000476 & 0,000003 & 0,1242 & 0,00054 & 0,19998 & 0,0006 & 2826,4 & 4,9 \\
\hline ML-20/30 & $30 / 30$ & 0,000027 & 0,000003 & 0,08741 & 0,00241 & 0,2013 & 0,00079 & 2837,1 & 6,4 \\
\hline Total & $94 / 140$ & & & & & Idade média & & $2830 \pm 13$ & \\
\hline \multicolumn{10}{|c|}{ Hornblenda-biotita metatonalito - ML-17 } \\
\hline ML-17/6 & $32 / 32$ & 0,000014 & 0,000005 & 0,18461 & 0,00108 & 0,20320 & 0,00046 & 2852,3 & 3,7 \\
\hline ML- & $34 / 34$ & 0,000011 & 0,000001 & 0,20 & 0,00094 & 0,2 & 0,00026 & 2849,5 & 2,1 \\
\hline ML- & $32 / 32$ & 0,000031 & 0,000002 & 0,17743 & 0,00083 & 0,2 & 0,00029 & 2854,5 & 2,3 \\
\hline ML-17/10 & $36 / 36$ & 0,000026 & 0,000003 & 0,18228 & 0,00103 & 0,20322 & 0,00041 & 2852,5 & 3,3 \\
\hline Total & $134 / 134$ & & & & & Idade média & & $2852 \pm 2$ & \\
\hline \multicolumn{10}{|c|}{ Biotita monzogranito - ML-08 } \\
\hline ML08/1 & $32 / 62$ & 0,000017 & 0,000008 & 0,05394 & 0,00075 & 0,17015 & 0,0006 & 2559,6 & 5,9 \\
\hline ML08/8 & $0 / 8$ & 0,000034 & 0,00001 & 0,08643 & 0,00053 & 0,15927 & 0,0004 & 2448,2 & 4,3 \\
\hline ML08/9 & $0 / 8$ & 0,000053 & 0,000042 & 0,05005 & 0,00541 & 0,15703 & 0,00622 & 2424,2 & 67,2 \\
\hline ML08/12 & $40 / 40$ & 0,000043 & 0,000006 & 0,05724 & 0,00022 & 0,17424 & 0,00028 & 2599,1 & 2,7 \\
\hline \multicolumn{10}{|c|}{ Hornblenda-biotita granodiorito - ML-16 } \\
\hline$M L-16 / 1$ & $38 / 38$ & 0,000193 & 0,000017 & 0,15721 & 0,00180 & 0,12231 & 0,00049 & 1990,5 & 7,1 \\
\hline$M L-16 / 2$ & $22 / 22$ & 0,000463 & 0,000004 & 0,35690 & 0,00768 & 0,12173 & 0,00045 & 1982,0 & 6,6 \\
\hline$M L-16 / 3$ & $14 / 14$ & 0,000062 & 0,000007 & 0,13067 & 0,00368 & 0,12278 & 0,00069 & 1997,2 & 10,0 \\
\hline ML-16/4 & $34 / 34$ & 0,000080 & 0,000003 & 0,12585 & 0,00271 & 0,12189 & 0,00047 & 1984,3 & 6,9 \\
\hline ML-16/12 & $28 / 36$ & 0,000463 & 0,000028 & 0,25518 & 0,00075 & 0,12255 & 0,00030 & 1993,8 & 4,4 \\
\hline Total & $136 / 144$ & & & & & Idade média & & $1990 \pm 7$ & \\
\hline \multicolumn{10}{|c|}{ Enderbito - ML-13 } \\
\hline$M L-13 / 4$ & $18 / 26$ & 0,000019 & 0,000003 & 0,2806 & 0,0010 & 0,1222 & 0,0005 & 1989,0 & 7,1 \\
\hline$M L-13 / 8$ & $28 / 76$ & 0,000481 & 0,000070 & 0,3481 & 0,0009 & 0,1223 & 0,0003 & 1989,5 & 4,7 \\
\hline$M L-13 / 9$ & $44 / 60$ & 0,000091 & 0,000043 & 0,2916 & 0,0288 & 0,1219 & 0,0002 & 1984,4 & 2,6 \\
\hline$M L-13 / 10$ & $56 / 68$ & 0,000022 & 0,000024 & 0,2928 & 0,0268 & 0,1224 & 0,0005 & 1991,0 & 7,5 \\
\hline ML-13/11 & $34 / 34$ & 0,000091 & 0,000005 & 0,3460 & 0,0017 & 0,1221 & 0,0003 & 1987,7 & 4,0 \\
\hline$M L-13 / 14$ & $34 / 74$ & 0,000164 & 0,000022 & 0,3227 & 0,0012 & 0,1227 & 0,0003 & 1995,7 & 4,8 \\
\hline Total & $214 / 338$ & & & & & Idade média & & $1989 \pm 4$ & \\
\hline
\end{tabular}

$\left.{ }^{207} \mathrm{~Pb} /{ }^{206} \mathrm{~Pb}\right) \mathrm{c}$ e $\left({ }^{208} \mathrm{~Pb} / 206 \mathrm{~Pb}\right) \mathrm{c}=$ razões corrigidas de $\mathrm{Pb}$ comum; ${ }^{\star}$ razões isotópicas consideradas no cálculo das idades/razões isotópicas medidas. 
intensas, sob as quais os cristais de feldspato são pouco afetados. Contudo, o plagioclásio tem comportamento mais rígido, relativamente ao feldspato potássico, como observaram Debat et al. (1978) e Vernon et al. (1983), que também fazem alusão à maior resistência dos cristais de plagioclásio em relação ao feldspato potássico e deste em comparação ao quartzo.

Em biotita granodiorito, hornblenda-biotita granodiorito e enderbito, orientações preferenciais de minerais isentos de forte deformação são critérios importantes na identificação de tramas magmáticas, como preconizam Paterson et al. $(1989,1998)$. A origem dessas estruturas precoces tem ligação com a rotação rígida de cristais prismáticos em um meio líquido (Vigneresse et al., 1996). Nesse sentido, tramas precoces se desenvolveram de modo mais efetivo, no estágio magmático não completamente consolidado, quando a quantidade de cristais ainda não era elevada. Tramas magmáticas nesse estágio são ainda mais facilitadas quando há cristais com hábitos prismáticos e cujos eixos maior e menor resultam em razões superiores a 3:1, a exemplo de feldspatos, anfibólio e biotita. O bandamento magmático rítmico subvertical, presente nas rochas da área, bem como os cristais com leve orientação, visíveis em escala microscópica, refletem fluxo ligado à ascensão e ao preenchimento de câmaras magmáticas.

Quanto à geocronologia, todos os cristais de zircão analisados das amostras do litotipo biotita metagranodiorito foram considerados como de origem ígnea, pois os zircões são geralmente euédricos e prismáticos. Isso leva a considerar que as idades obtidas podem ser interpretadas como idades de cristalização e, consequentemente, de colocação das rochas que os contêm. Entretanto, idades obtidas nas variedades desse litotipo (ML-04: $3066 \pm 3$ Ma e ML-20: $2830 \pm 13 \mathrm{Ma}$ ) mostram diferenças expressivas, pois não se superpõem, quando se leva em conta os erros analíticos. Isto não é facilmente explicável, pois não há evidências conclusivas que justifiquem as duas idades para o mesmo litotipo. Uma hipótese a avaliar seria a de que esse litotipo foi formado por pulsos magmáticos que se sucederam, porém o tempo é relativamente longo (3066 a $2830 \mathrm{Ma})$. Nesse caso, essas rochas não corresponderiam a uma única intrusão, mas pelo menos duas intrusões não sincrônicas, que posteriormente seriam afetadas por processos deformacionais. Outra hipótese seria admitir que a idade obtida para a amostra ML-20 não corresponderia rigorosamente à sua idade de cristalização, sendo de fato a idade "máxima" para a colocação do plúton, resultante de perdas parciais de $\mathrm{Pb}$ radiogênico. Essa possibilidade tem como base os sinais de metamitização observados em alguns cristais analisados dessa amostra. Mesmo assim, a menor idade tem uma precisão relativamente alta, e a diferença de idade é também alta demais (237 Ma) para que essa hipótese seja verdadeira.

Analisando a questão com outro enfoque, observase a idade de $3137 \pm 8 \mathrm{Ma}$, obtida em grãos da amostra ML-04. A interpretação aqui apresentada, de que os cristais analisados consistem em grãos herdados, tem como base dados inéditos de Nd (Corrêa, 2012). Esses dados apontam para a extração desse magma do manto em torno de $3,15 \mathrm{Ga}$ e, por se tratar de um granodiorito, relativamente evoluído em termos de teor de sílica, não é de se esperar que a idade de $3137 \pm 8$ Ma seja a idade de cristalização dessa rocha. Dessa forma, acredita-se que houve extração do manto de um magma menos evoluído em torno de $3,15 \mathrm{Ga}$, cristalização de minerais, incluindo o zircão, e em outra fusão parcial, geração de um magma granodiorítico. Assim, a interpretação preferida no momento é que esses cristais de zircão de cerca de $3,15 \mathrm{Ga}$ teriam sido incorporados a um magma granodiorítico que, em seguida, foi colocado e cristalizado na crosta em torno de $3066 \pm 3 \mathrm{Ma}$ e, posteriormente, deformado em várias intensidades.

A idade obtida para a amostra ML-17 (hornblendabiotita metatonalito) de $2852 \pm 2$ Ma pode ser admitida como sendo a idade de cristalização e colocação desse tonalito no domínio leste da área. As evidências texturais indicam que a deformação imposta à rocha foi processada depois de sua completa cristalização que, possivelmente, não provocou perda de $\mathrm{Pb}$ e, consequentemente, não afetou a idade de cristalização.

Os resultados isotópicos para a amostra ML-08, que correspondem ao biotita monzogranito, não indicaram uma idade precisa, com valores dispersos, variando entre 2599 e $2424 \mathrm{Ma}$, o que não permitiu calcular uma idade média para os grãos analisados. Os cristais de zircão selecionados apresentam núcleos mais escuros que suas bordas, levando à interpretação de que se trata de processos de metamitização, presença de cristais herdados de diferentes gerações ou ainda núcleos antigos manteados por bordas mais jovens, produzidas por injeções de magmas posteriores aos que originaram esses núcleos escurecidos. Como o método de evaporação de $\mathrm{Pb} \mathrm{em}$ monocristal de zircão não possui resolução espacial devido à evaporação total do grão, o que possivelmente o torna inapropriado para datar cristais complexos, é provável que tais fatos geraram a dispersão de idades entre os cristais analisados. No entanto, as relações de campo atestam que o biotita monzogranito é intrusivo no biotita metagranodiorito, inclusive portando enclaves desse último litotipo que são encontrados com certa frequência dentro do biotita monzogranito. 
As amostras de hornblenda-biotita granodiorito (ML-16) e de enderbito (ML-13) forneceram idades bastante similares de $1990 \pm 7 \mathrm{Ma}$ e $1989 \pm 4 \mathrm{Ma}$, respectivamente, ambas intrepretadas como sendo o tempo de cristalização e colocação desses corpos. Levando-se em conta os desvios sobre as idades e as feições geológicas que relacionam os dois tipos de rochas, interpreta-se que a colocação dos dois plútons tenha ocorrido sincronicamente, apesar de aparentemente representarem níveis crustais distintos.

Não foram realizadas análises para atestar as semelhanças geoquímicas que permitissem avaliar se esses magmas teriam a mesma filiação magmática, ou não. Contudo, de acordo com Frost et al. (2000), magmas anidros se movem a partir de porções mais profundas da crosta para os níveis mais rasos, de menor pressão, permitindo que processos de hidratação e cristalização fracionada se tornem cada vez mais factíveis, de forma que as rochas geradas diretamente pelo magma anidro acabam sendo representadas apenas por porções isoladas entre rochas relativamente hidratadas. Partindo do exposto, processos de cristalização fracionada e hidratação de magma anidro poderiam justificar a exposição dos blocos isolados de enderbito encontrados no interior da grande exposição de hornblenda-biotita granodiorito da área, com ambos os litotipos apresentando idades similares. É importante comentar que é comum a presença de anfibólio com núcleo portador de relictos de piroxênio no hornblenda-biotita granodiorito, que possivelmente poderia confirmar esse processo de hidratação e, dessa forma, tentativamente explicaria uma cogeneticidade entre essas rochas.

\section{CONCLUSÕES}

Os levantamentos geológicos e a caracterização petrográfica permitiram a individualização de cinco litotipos na região de Santana do Araguaia (PA), a saber: biotita monzogranito, biotita metagranodiorito, hornblenda-biotita granodiorito, hornblenda-biotita metatonalito e enderbito.

Os litotipos biotita monzogranito, biotita metagranodiorito e hornblenda-biotita granodiorito são denominados na proposta de Macambira et al. (2007) de Ortognaisse Rio Campo Alegre, Complexo Santana do Araguaia e Tonalito Rio Dezoito, respectivamente. Nesse sentido, sugerimos que a definição dessas unidades seja revista, pois o que é caracterizado como Ortognaisse Rio Campo Alegre, na realidade, é uma intrusão ígnea granítica, com bandamento magmático e textura ígnea preservada. De acordo com nossos dados, as unidades Complexo Santana do Araguaia e Tonalito Rio Dezoito perfazem um conjunto de biotita metagranodioritos, deformados com trend estrutural predominantemente $\mathrm{E}-\mathrm{W}$, e não NW-SE, como proposto em trabalhos anteriores (Vasquez et al., 2008).

Os litotipos hornblenda-biotita metatonalito e enderbito são novas unidades, identificadas durante o desenvolvimento deste trabalho.

Assim, a partir da integração dos dados geológicos, estruturais, petrográficos e geocronológicos, foi possível chegar às conclusões que apresentamos na sequência.

O biotita metagranodiorito é o granitoide arqueano mais antigo da região (3066 $\pm 3 \mathrm{Ma})$, tendo sido intrudido pelos demais granitoides da região.

Após um período de cerca de 200 milhões de anos sem registro de formação de rochas, deu-se a intrusão do hornblenda-biotita tonalito em $2852 \pm 2 \mathrm{Ma}$. Seguindo a colocação e cristalização dessa rocha, pode-se inferir a instalação de zonas de cisalhamento afetando esse litotipo e transformando-o em um hornblenda-biotita metatonalito. Os estudos das feições em escala macro e microscópica sugerem uma zona de cisalhamento dúctil, transcorrente, com direção predominante NW-SE, sinistral, evidenciada pelas características deformacionais nas amostras ML-14, ML-17 (porção leste da área). Porém, não é observado esse padrão deformacional nas amostras ML-04 e ML-20 (biotita metagranodiorito), as mais antigas da região, porção centro-sul e norte da área, que apresentam direção da foliação aproximadamente E-W. Isso ocorre, possivelmente, pelo fato de essa zona de cisalhamento ser local, com pouca abrangência areal.

Levando em conta as idades das rochas e o trend deformacional, pode-se, tentativamente, estimar quando os eventos deformacionais ocorreram. $\mathrm{O}$ evento deformacional de direção E-W é o mais antigo da região, pois está marcado no biotita metagranodiorito, rocha mais antiga encontrada. É importante comentar que esse trend é concordante com o registrado nas rochas do TGGRM. Posteriormente, após a colocação e cristalização do hornblenda-biotita tonalito, ocorreu um cisalhamento de direção NW-SE na porção leste da área, afetando essa rocha e transformando-a em hornblendabiotita metatonalito. Entretanto, ela não afetou o biotita metagranodiorito. Ainda pode-se dizer que esse evento deformacional de direção NW-SE é mais velho que o hornblenda-biotita granodiorito e enderbito, pois não há registro dessa deformação nessas rochas.

Após a colocação do hornblenda-biotita metatonalito, ocorreu a colocação do biotita monzogranito. Esta rocha apresenta cristais de zircão com idades que 
variam entre 2599 e $2424 \mathrm{Ma}$. O biotita monzogranito é intrusivo no biotita metagranodiorito, rocha mais antiga da região. Essa relação é atestada pelas relações de campo, pois é comum enclaves do biotita metagronodiorito serem encontrados dentro do biotita monzogranito.

Finalmente, após aproximadamente 1,1 bilhão de anos, houve a intrusão de corpos graníticos representados por horblenda-biotita granodiorito e enderbito, com idades de $1990 \pm 7$ Ma e $1989 \pm 4$ Ma, respectivamente. Idade próxima a essas foi obtida em um granodiorito no Domínio Bacajá em torno de $1986 \pm 5$ Ma (Vasquez et al., 2005) que, segundo Vasquez (2006), poderia representar um pulso magmático tardio do Evento Transamazônico, relacionado ao estágio pós-orogênico ou, alternativamente, ter evolução relacionada ao orógeno orosiriano $(2,03-$ 1,96 Ga) do Domínio Tapajós, Província Tapajós-Parima, posicionado em região de antepaís.

Por fim, os dados geológicos, petrográficos, estruturais e principalmente geocronológicos obtidos neste trabalho levam a interpretar a região de Santana do Araguaia como a continuidade do TGGRM para sudoeste, pois inexistem evidências claras de eventos metamórficos regionais de cerca de 2,2 - 1,9 Ga (Tassinari e Macambira, 2004; Ciclo Transamazônico) nas rochas descritas na área estudada, que poderiam levar à separação em dois domínios distintos, embora se diferenciem pela presença de rochas paleoproterozoicas distintas daquelas encontradas no DRM.

Os dados estruturais de direção NW-SE, que são característicos do Evento Transamazônico no Domínio Bacajá, são localizados na porção leste da área de estudo, não se estendendo por toda a região estudada. É importante comentar que esse evento não registra metamorfismo nas rochas influenciadas por essa deformação, nem afeta as rochas mais antigas encontradas, que apresentam foliação com trend dominantemente E-W. No entanto, datações por métodos sensíveis a eventos térmicos associados a possíveis metamorfismos regionais devem ser aplicados para elucidar definitivamente a questão.

\section{AGRADECIMENTOS}

Os autores agradecem ao $\mathrm{MCT} / \mathrm{CNPq}$ (Processo $\mathrm{n}^{\circ}$. 484571/2007-9) pelo apoio financeiro e a CAPES pela concessão de bolsa de estudo. Agradecemos também ao geólogo Francisco Coelho/IBGE pelas discussões durante os trabalhos de campo, aos revisores deste artigo com grande contribuição na melhora do mesmo e a Moacir Macambira pelas orientações durante o desenvolvimento deste trabalho.

\section{REFERÊNCIAS}

Almeida, J. A. C., Dall'agnol, R., Dias, S. B., Althoff, F. J. (2010). Origin of the Archean leucogranodioritegranite suites: Evidence from the Rio Maria terrane and implications for granite magmatism in the Archean. Lithos, 120(3), 235-257.

Almeida, J. A. C., Dall'agnol, R., Oliveira, M. A., Macambira, M. J. B., Pimentel, M. M., Rämö, O. T., Guimarães, F. V., Leite, A. A. S. (2011). Zircon geochronology, geochemistry and origin of the TTG suites of the Rio Maria granite-greenstone terrane: Implications for the growth of the Archean crust of Carajás Province, Brazil. Precambrian Research, 187(1), 201-221.

Almeida, J. A. C., Oliveira, M. A., Dall'agnol, R., Althoff, F. J., Borges, R. M. K. (2008). Relatório de mapeamento geológico na escala 1:100.000 da Folha Marajoara (SB22-ZC V). Brasília: Programa Geobrasil, CPRM - Serviço Geológico do Brasil.

Althoff, F. J., Barbey, P., Boullier, A. M. (2000). 2.8 3.0 Ga plutonism and deformation in the SE Amazonian Craton: the Archean granitoids of Marajoara (Carajás Mineral province, Brazil). Precambrian Research, 104, 187-206.

Althoff, F. J., Barbey, P., Macambira, M. J. B., Scheller, T., Leterrier, J., Dall'agnol, R., Lafon, J. M. (1998). La croissance du Craton sud-amazonien (région de Rio Maria, Brésil). XVII Réunion des Sciences de la Terre, Resumés, p. 62. Brest: Société Géologique de France.

Barros, C. E. M., Krymsky, R., Sardinha A. S. (2006). Geology, geochemistry, and U-Pb geochronology of the Archean $(2.74 \mathrm{Ga})$ Serra do Rabo granite stocks, Carajás Metallogenetic Province, northern Brazil. Journal of South American Earth Sciences 20(4), 327-339.

Barros, M. P. S., Padilha, R. A., Rubert, R. R., Pimentel, M. M., Silva, G. D. (2005). Idade U-Pb para o granito Rio Dourado e sua correlação com o vulcanismo Iriri (Província Amazônia Central - Cráton Amazônico, nordeste de Mato Grosso). IX Simpósio de Geologia do Centro-Oeste, 105107. Goiânia: SBG - Núcleo Centro-Oeste.

Bowden, P., Batchelor, R. A., Chapell, B. W., Didier, J., Lameyre, J. (1984). Petrological, geochemical and source criteria for the classification of granitic rocks: a discussion. Physics of the Earth and Planetary Interiors, 35(1-3), 1-11. 
Corrêa, L. W. C. (2012). Geologia e geocronologia Pb-Pb em zircão e Sm-Nd em rocha total de granitoides da região de Santana do Araguaia-PA. Dissertação (Mestrado). Belém: Instituto de Geociências - UFPA.

Cunha, B. C. C., Potiguar, L. A. T., Ianhez, A. C., Bezerra, P. E. L., Pithan, J. H. L., Souza Júnior, J. J., Montalvão, R. M. G., Souza, A. M. S., Hildred, P. R., Tassinari, C. C. G. (1981). Folha SC. 22 Tocantins: geologia, geomorfologia, pedologia, vegetação e uso potencial da terra / Projeto RADAMBRASIL, Levantamento de Recursos Naturais. Rio de Janeiro: Programa de Integração Nacional - Projeto RADAMBRASIL.

Dall'agnol, R., Oliveira, M. A. Almeida, J. A. C., Althoff, F. J., Leite, A. A. S., Oliveira, D. C., Barros, C. E. M. (2006). Archean and Paleoproterozoic granitoids of the Carajás metallogenic province, eastern Amazonian Craton. Symposium on Magmatism, Crustal Evolution, and Metallogenesis of the Amazonian Craton, Excursion Guide, 99-150. Belém: Centro de Geociências - UFPA.

Dall'agnol, R., Rämö, O. T., Magalhães, M. S., Macambira, M. J. B. (1999). Petrology of the anorogenic, oxidised Jamon and Musa granites, Amazonian Craton: implications for the genesis of Proterozoic A-type granites. Lithos, 46(3), 431-462.

Dall'Agnol, R., Teixeira, N. P., Rämö, O. T., Moura, C. A. V., Macambira, M. J. B., Oliveira, D. C. (2005). Petrogenesis of the Paleoproterozoic rapakivi A-type granites of the Archean Carajás metallogenic province, Brazil. Lithos, 80(1), 101-129.

Debat, P., Soula, J. C., Kubin, L., Vidal, J. L. (1978). Optical studies of natural deformation microstructures in feldspars (gneiss and pegmatites from Occitania, southern France). Lithos, 11(2), 133-145.

Faraco, M. T. L., Marinho, P. A. C., Vale, A. G., Costa, E. J. S., Ferreira, A. L., Valente, C. R., Lacerda Filho, J. V., Moreton, L. C., Camargo, L. C., Camargo, M. A., Frasca, A. A., Ribeiro, P. S. E., Vasconcelos, A. M., Oliveira, M., Oliveira, I. W. B., Abreu Filho, W., Gomes, I. P. (2004). Folha SC. 22 Tocantins: geologia, geomorfologia, pedologia, vegetação, uso potencial da terra. In: C. Schobbenhaus, J. H. Gonçalves, J. O. S. Santos, M. B. Abram, R. Leão Neto, G. M. M. Matos, R. M. Vidotti, M. A. B. Ramos, J. D. A. Jesus (Eds.), Carta Geológica do Brasil ao Milionésimo, Sistema de Informações Geográficas. Programa Geologia do Brasil. Brasília: CPRM. CD-ROM.
Frost, B. R., Frost, C. D., Hulsebosch, T. P., Swapp, S. M. (2000). Origin of the charnockites of the Louis Lake batholith, Wind River Range, Wyoming. Journal of Petrology, 41(12), 1759-1776.

Gaudette, H. E., Lafon, J. M., Macambira, M. J. B., Moura, C. A. V., Scheller, T. (1998). Comparison of single filament $\mathrm{Pb}$ evaporation/ionization zircon ages with conventional $\mathrm{U}-/ \mathrm{Pb}$ results: examples from the Precambrian of Brazil. Journal of South American Earth Sciences, 11(4), 351-363.

Kober, B. (1987). Single-zircon evaporation combined with $\mathrm{Pb}$ emitter bedding $207 \mathrm{~Pb} / 206 \mathrm{~Pb}$-age investigations using thermal ion mass spectrometry, and implications to zirconology. Contribution to Mineralogy and Petrology, 96, 63-71.

Lameyre, J., Bowden, P. (1982). Plutonic rock type series: discrimination of various granitoid series and related rocks. Journal of Volcanology and Geothermal Research, 14, 169-186.

Leite, A. A. S. (2001). Geoquímica, petrogênese e evolução estrutural dos granitoides arqueanos da região de Xinguara, SE do Cráton Amazônico. Tese (Doutorado). Belém: Centro de Geociências - UFPA.

Leite, A. A. S., Dall'agnol, R., Macambira, M. J. B., Althoff, F. J. (2004). Geologia e Geocronologia dos granitoides Arqueanos da região de Xinguara-PA e suas implicações na evolução do Terreno Granito-Greenstone de Rio Maria, Cráton Amazônico. Revista Brasileira de Geociências, 34(4), 447-458.

Macambira, E. M. B., Vasquez, M. L., Ricci, P. S. F. (2007). Caracterização do Domínio Tectônico Santana do Araguaia - Sudeste Do Pará. X Simpósio de Geologia da Amazônia, Resumos Expandidos. Porto Velho: SBG Núcleo Norte. CD-ROM.

Macambira, M. J. B. (1992). Chronologie U/Pb, $R b / S r$, $K / A r$ et croissance de la croûte continentale dans L'Amazonie du sud-est; exemple de la région de Rio Maria, Province de Carajás, Brésil. (Ph.D.) Thesis. Montpellier: Université Montpellier II - UM2.

Macambira, M. J. B., Costa, J. B. S., Althoff, F. J., Lafon, J. M., Melo, J. C. V., Santos, A. (2000). New geochronological data for the Rio Maria TTG Terrane, implications for the time constraints of the crustal formation of the Carajás province, Brazil. XXXI International Geological Congress. Rio de Janeiro: Versão Brasileira e IGC. CD-ROM. 
Macambira, M. J. B., Lafon, J. M. (1995). Geocronologia da Província Mineral de Carajás; Síntese dos dados e novos desafios. Boletim do Museu Paraense Emílio Goeldi, 7, 263-287.

Monteiro, P. C., Rolando, A. P., Macambira, M. J. B. (2004). Proveniência de zircão de quartzitos da Formação Gorotire e Grupo Rio Fresco, Serra do Inajá, sul da Província Mineral do Carajás. XLII Congresso Brasileiro de Geologia, Resumos. Araxá: SBG. CD-ROM.

Oliveira, M. A., Dall'agnol, R., Althoff, F. J., Leite, A. A. S. (2009). Mesoarchean sanukitoid rocks of the Rio Maria Granite-Greenstone Terrane, Amazonian Craton, Brazil. Journal of South American Earth Sciences, 27(2), 146-160.

Paterson, S. R., Fowler Jr., T. K., Schmidt, K. L., Yoshinobu, A. S., Yuan, E. S., Miller, R. B. (1998). Interpreting magmatic fabric patterns in plutons. Lithos, 44(1-2), 53-82.

Paterson, S. R., Vernon, R. H., Tobisch, O. T. (1989). A review of criteria for the identification of magmatic and tectonic foliations in granitoids. Journal of Structural Geology, 11(3), 349-363.

Pimentel, M. M., Machado, N. (1994). Geocronologia $\mathrm{U}-\mathrm{Pb}$ dos terrenos granito-greenstone de Rio Maria, Pará. XXXVIII Congresso Brasileiro de Geologia, Boletim de Resumos Expandidos, 390-391. Camboriú: SBG.

Rolando, A. P., Macambira, M. J. B. (2002). Geocronologia dos granitoides arqueanos da região da Serra do Inajá, novas evidências sobre a formação da crosta continental no sudeste do Cráton Amazônico, SSE Pará. XLI Congresso Brasileiro de Geologia, Boletim de Resumos Expandidos, p. 525. João Pessoa: SBG.

Rolando, A. P., Macambira, M. J. B. (2003). Archean crust formation in Inajá range area, SSE of Amazonian Craton, Brazil, based on zircon ages and $\mathrm{Nd}$ isotopes. IV South American Symposium on Isotope Geology, Expanded Abstract. Salvador: CBPM. CD-ROM.

Santos, J. O. S. (2003). Geotectônica do Escudo das Guianas e Brasil-Central. In: L. A. Bizzi, C. Schobbenhaus, R. M. Vidotti, J. H. Gonçalves (Eds.), Geologia, tectônica e recursos minerais do Brasil: texto, mapas e SIG (169226). Brasília: CPRM.

Silva, G. G., Lima, M. I. C., Andrade, A. R. F., Issler, R. S., Guimarães, G. (1974). Folhas SB. 22 Araguaia e parte da Folha SC. 22 Tocantins: geologia, geomorfologia, pedologia, vegetação e uso potencial da terra / Projeto RADAMBRASIL, Levantamento de Recursos Naturais. Rio de Janeiro: Programa de Integração Nacional - Projeto RADAMBRASIL.

Smith, J.V. (1974). Feldspar minerals. New York: Springer-Verlag.

Stacey, J. S., Kramers, J. D. (1975). Approximation of terrestrial lead isotope evolution by a two-stage model. Earth and Planetary Science Letters, 26(2), 207-221.

Streckeisen, A. L. (1976). To each plutonic rock its proper name. Earth Science Reviews, 12(1), 1- 33.

Tassinari, C. C. G., Basei, M. A. S. (1980). Primeiros resultados arqueanos em migmatitos da região da serra do Tapirapé, Mato Grosso. XXXI Congresso Brasileiro de Geologia, Anais, v. 5, 2744-2751. Camboriú: SBG.

Tassinari, C. C. G., Macambira, M. J. B. (1999). Geochronological provinces of the Amazonian Craton. Episodes, 22(3), 174-182.

Tassinari, C. C. G., Macambira, M. J. B. (2004). A evolução tectônica do Cráton Amazônico. In: V. Mantesso-Neto, A. Bartorelli, C. D. R. Carneiro, B. B. Brito Neves (Orgs.), Geologia do Continente Sul Americano: Evolução da obra de Fernando Flávio Marques Almeida (471-486). São Paulo: Beca.

Vasquez, M. L. (2006). Geocronologia em zircão, monazita e granada e isótopos de Nd das associações litológicas da porção oeste do Domínio Bacajá: evolução crustal da porção meridional da província Maroni-Itacaiúnas, sudeste do Cráton Amazônico. Tese (Doutorado). Belém: Centro de Geociências - UFPA.

Vasquez, M. L., Macambira, M. J. B., Galarza Toro, M. A. (2005). Granitoides transamazônicos da Região Iriri-Xingu, Pará - Novos dados geológicos e geocronológicos. In: A. M. C. Horbe, V. S. Souza (Coords.), Contribuições à geologia da Amazônia (v. 4, 16-31). Manaus: SBG - Núcleo Norte.

Vasquez, M. L., Macambira, E. M. B., Lafon, J. M., Galarza, M. A. (2007). Datação por evaporação de $\mathrm{Pb}$ em zircão de ortognaisses e granitoides da região de Santana do Araguaia - Sudeste do Pará. X Simpósio de Geologia da Amazônia, Resumos Expandidos. Porto Velho: SBG Núcleo Norte. CD-ROM. 
Vasquez, L. V., Rosa-costa, L. R., Silva, C. G., Ricci, P. F., Barbosa, J. O., Klein, E. L., Lopes, E. S., Macambira, E. M. B., Chaves, C. L., Carvalho, J. M., Oliveira, J. G., Anjos, G. C., Silva, H. R. (2008). Geologia e recursos minerais do Estado do Pará. Sistema de informações geográficas: texto explicativo dos mapas geológico e tectônico e de recursos minerais do Estado do Pará. Escala 1:1.000.000. Belém: CPRM.
Vernon, R. H., Williams, V. A., D'arcy, W. F. (1983). Grainsize reduction and foliation development in a deformed granitoid Batholith. Tectonophysics, 92(1), 123-145.

Vigneresse, J. L, Barbey, P., Cuney, M. (1996). Rheological transitions during partial melting and crystallization with application to felsic magma segregations and transfer. Journal of Petrology, 37(6), 1579-1600. 